\title{
Pseudomonas fluorescens PTA-CT2 Triggers Local and Systemic Immune Response Against Botrytis cinerea in Grapevine
}

\author{
Charlotte Gruau, Patricia Trotel-Aziz, Sandra Villaume, Fanja Rabenoelina, Christophe Clément, \\ Fabienne Baillieul, and Aziz Aziz
}

URVVC EA 4707, SDRP, University of Reims, UFR Sciences, Campus Moulin de la Housse, 51687 Reims Cedex 02 , France

Submitted 23 April 2015. Accepted 9 June 2015.

\begin{abstract}
Although induced systemic resistance (ISR) is well-documented in the context of plant-beneficial bacteria interactions, knowledge about the local and systemic molecular and biochemical defense responses before or upon pathogen infection in grapevine is very scarce. In this study, we first investigated the capacity of grapevine plants to express immune responses at both above- and below-ground levels upon interaction with a beneficial bacterium, Pseudomonas fluorescens PTA-CT2. We then explored whether the extent of priming state could contribute to the PTACT2-induced ISR in Botrytis cinerea-infected leaves. Our data provide evidence that this bacterium colonized grapevine roots but not the above-ground plant parts and altered the plant phenotype that displayed multiple defense responses both locally and systemically. The grapevine roots and leaves exhibited distinct patterns of defense-related gene expression during root colonization by PTA-CT2. Roots responded faster than leaves and some responses were more strongly upregulated in roots than in leaves and vice versa for other genes. These responses appear to be associated with some induction of cell death in roots and a transient expression of $H S R$, a hypersensitive responserelated gene in both local (roots) and systemic (leaves) tissues. However, stilbenic phytoalexin patterns followed opposite trends in roots compared with leaves but no phytoalexin was exuded during plant-bacterium interaction, suggesting that roots could play an important role in the transfer of metabolites contributing to immune response at the systemic level. Unexpectedly, in B. cinerea-infected leaves PTA-CT2-mediated ISR was accompanied in large part by a downregulation of different defense-related genes, including $H S R$. Only phytoalexins and glutathion- $S$ transferase 1 transcripts were upregulated, while the expression of anthocyanin biosynthetic genes was maintained at a higher level than the control. This suggests that decreased expression of $H S R$, as a marker of cell death, and activation of secondary metabolism pathways could be responsible for a reduced B. cinerea colonization capacity in bacterized plants.
\end{abstract}

The rhizosphere microbiome harbors a wide diversity of fungal and bacterial species with beneficial effects on plant growth and health (Bakker et al. 2007; Berendsen et al. 2012;

Corresponding author: A. Aziz; Telephone: +33 326918 525;

E-mail: aziz.aziz@univ-reims.fr

*The $\boldsymbol{e}$-Xtra logo stands for "electronic extra" and indicates that five supplementary figures and one supplementary table are published online.

(c) 2015 The American Phytopathological Society
Lugtenberg and Kamilova 2009; Mendes et al. 2011; Pieterse et al. 2012). Several bacteria, especially Pseudomonas and Bacillus spp., have been shown to promote plant growth and to trigger a plant-mediated resistance response in above-ground plant parts against fungal, oomycete, bacterial, and viral pathogens as well as against insects (De Vleesschauwer and Höfte 2009; Pineda et al. 2010; Van der Ent et al. 2009; van Loon et al. 1998). Triggered plant resistance exploits mechanisms of the plant immune system, and two phenotypically similar forms of systemic immunity have, so far, been identified in plants, i.e., systemic acquired resistance (SAR) and induced systemic resistance (ISR) (Pieterse et al. 2012). While SAR is activated systemically following necrotizing pathogen recognition or treatment with some chemicals (Pieterse et al. 2012), ISR can be activated by specific strains of nonpathogenic bacteria or fungi (Van der Ent et al. 2009; Zamioudis and Pieterse 2012). Immune response in plants is initiated upon receptor-mediated perception of non-self molecules that are often conserved among both pathogenic and beneficial microbes. These molecules are denoted microbeassociated molecular patterns (MAMPs), and MAMP-induced defense responses in host plants are referred to as MAMPtriggered immunity (MTI) (Boller and Felix 2009; Jones and Dangl 2006). The large majority of studies have reported that, unlike SAR, bacteria-mediated ISR functions in a salicylic acid (SA)-independent manner and is not marked by the transcriptional activation of pathogen-related (PR) genes (Pieterse et al. 1996; van Wees et al. 1997, 1999). In many cases, ISR is mediated by jasmonic acid (JA) and ethylene (ET) signaling and requires the transcriptional regulator NPR1, a key regulator in SA signaling (Pieterse et al. 2012; Van der Ent et al. 2009; van Wees et al. 1997; 1999; Zamidiou and Pieterse 2012).

ISR is characterized by broad-spectrum activity against various types of pathogens and usually involves the activation of a priming state that provides plants with an enhanced capacity for rapid and strong activation of cellular defense responses only after pathogen infection (Conrath et al. 2006; Pozo et al. 2008; Van der Ent et al. 2009; van Hulten et al. 2006; Verhagen et al. 2004). The primed responses include oxidative burst (Iriti and Faoro 2003; Verhagen et al. 2010), induced expression of defense-related genes (Van Peer et al. 1991; van Wees et al. 1999; Verhagen et al. 2004), cell-wall reinforcement (Benhamou and Bélanger 1998), and the production of secondary metabolites after pathogen infection (Verhagen et al. 2011; Yedidia et al. 2003; Zdor and Anderson 1992). While SAR is related to localized necrotic lesions, beneficial bacteria-mediated ISR is not usually associated to phenotypic change prior to pathogen challenge (van Loon et al. 1998). The discrepancies between these two forms of systemic resistance might explain why ISR initiation 
has been proposed to come with lower fitness-cost for the plant compared with SAR (van Hulten et al. 2006; Walters and Heil 2007).

Accumulating evidence suggests that beneficial microorganisms such as bacteria are initially perceived as potential invaders, resulting in the activation of the plant immune system (Zamioudis and Pieterse 2012). Root colonization by selected strains of nonpathogenic bacteria triggered defense responses both locally in roots and systemically in noncolonized leaves of Arabidopsis thaliana (Millet et al. 2010; Zamioudis and Pieterse 2012). The induced state of ISR is not associated with major changes in defense-related gene expression (Verhagen et al. 2004), although an upregulation of some transcription factors and $P R$ genes upon interaction has been reported (LéonKloosterziel et al. 2005; Timmusk and Wagner 1999; Van der Ent et al. 2008; 2009; Verhagen et al. 2004; Wang et al. 2005). Nevertheless, at later stages of the interaction, various beneficial microbes have been shown to short-circuit host immune response, initially expressed in roots upon MAMP perception, to establish a successful colonization of the roots (Millet et al. 2010; Pel and Pieterse 2013; Zamioudis and Pieterse 2012). Instead, upon pathogen infection, ISR-expressing plants are primed to express a specific set of JA- or ET-responsive genes faster and to a higher level (van Wees et al. 1999; Verhagen et al. 2004). This enhanced defensive capacity allows the plants to respond more quickly and strongly to pathogens without major metabolic changes in the absence of an attacker (Conrath et al. 2006).

Induced resistance by beneficial bacteria has also been investigated in grapevine plants against the necrotrophic pathogen Botrytis cinerea (Ait Barka et al. 2000; Bordiec et al. 2011; Compant et al. 2013; Magnin-Robert et al. 2007; Trotel-Aziz et al. 2008; Verhagen et al. 2010, 2011). In recent studies, we assessed a collection of beneficial bacteria isolated from vineyards, including Pseudomonas fluorescens PTA-CT2, for their capacity to elicit and potentiate defense responses and ISR in grapevine leaves and berries against $B$. cinerea (Magnin-Robert

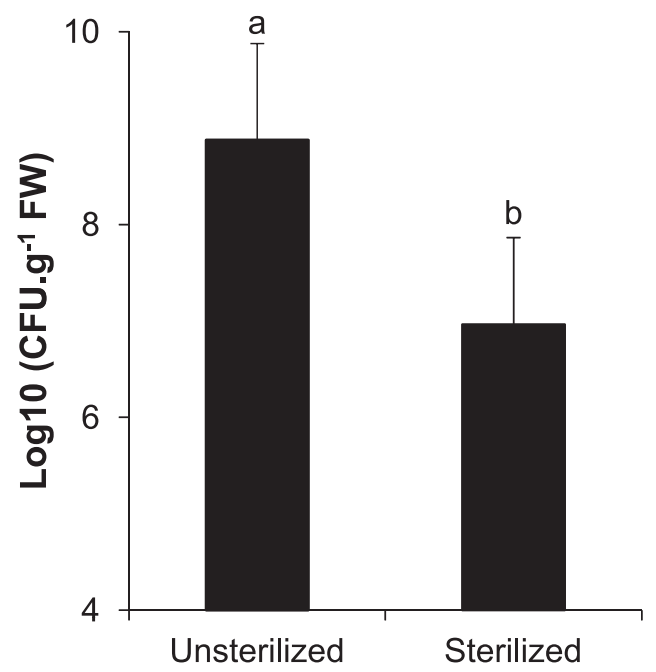

Fig. 1. Pseudomonas fluorescens PTA-CT2 colonizes grapevine roots. Plantlets were inoculated at the root level with PTA-CT2 at $2 \times 10^{7} \mathrm{CFU} \mathrm{ml}^{-1}$. The number of CFU per gram of fresh weight was evaluated in surfacesterilized and unsterilized roots of PTA-CT2-treated plants at 5 days postbacterization. Unsterilized roots contain CFU from the rhizoplane and the endosphere, whereas surface-sterilized roots contain CFU from the endosphere only. No CFU were detected in the sterilization control (last washing water) of surface-sterilized roots. The results are means from two experiments and are represented on a logarithmic scale. Vertical bars indicate standard errors $(n=24)$ and different letters indicate statistically significant differences (analysis of variance test, $P<0.05$ ). et al. 2007; Trotel-Aziz et al. 2008; Verhagen et al. 2011). Likewise, Burkholderia phytofirmans PsJN is able to induce defense responses in cell suspensions (Bordiec et al. 2011) and confers better protection against $B$. cinerea (Ait Barka et al. 2000). Cell extracts from various ISR-inducing rhizobacteria, including $P$. fluorescens PTA-CT2, and their culture media also triggered immune responses in grapevine cell suspensions and leaves (Verhagen et al. 2010; 2011) resembling those achieved by various purified MAMPs (Aziz et al. 2006, 2007; Trouvelot et al. 2008; Varnier et al. 2009).

Despite the fact that immune response and ISR have been extensively reported in the above-ground plant tissues over the past years, little information is available about MTI in roots as the favorite part for beneficial microbe colonization. Only recently, roots have been well recognized as playing an important role in above-ground defense mechanisms (Balmer et al. 2013; Millet et al. 2010; Zamioudis and Pieterse 2012). It has also been agreed that roots function as sink tissues that sequester portioned assimilates for growth recovery after herbivore attack (Erb et al. 2009; Gulati et al. 2014; Schwachtje et al. 2006). The importance of roots in synthesizing secondary metabolites involved in leaf defenses has been emphasized in different species (Ober and Kaltenegger, 2009; Ziegler and Facchini, 2008). These changes in root metabolism can exert a beneficial effect on above-ground attackers (Gulati et al. 2014; Kaplan et al. 2008; Marti et al. 2013).

Up to now, to unravel defense mechanisms associated to MAMP- or bacteria-induced resistance in grapevine, emphasis was placed only on immune response that leaves or berries could express. However, knowledge about the local (roots) molecular and biochemical defense responses compared with the systemic (leaves) defenses before or after pathogen infection is scarce. In this study, we first investigated the capacity of grapevine plants to express immune responses at both the above- and below-ground level upon interaction with the beneficial bacterium $P$. fluorescens PTA-CT2. We assessed the reactions of the plant at the phenotypic, transcriptional, and metabolic levels, showing differential immune responses in local and systemic tissues during root colonization by PTACT2. We then explored whether the extent of priming state could contribute to the PTA-CT2-induced ISR, by following the transcriptional response of defense-related genes and phytoalexin accumulation in $B$. cinerea-infected leaves. Our data also provide evidence that only a few defense responses are upregulated during ISR against $B$. cinerea in systemic tissues.

\section{RESULTS}

PTA-CT2 colonizes grapevine roots.

P. fluorescens PTA-CT2 (hereafter PTA-CT2) has been shown to induce ISR in grapevine plants against $B$. cinerea (Magnin-Robert et al. 2007; Verhagen et al. 2011). To determine if PTA-CT2-mediated ISR is associated with plant colonization by this bacterium, root and shoot colonization was measured following rhizoinoculation of 8-week-old grapevine plantlets with the beneficial bacterium. At 5 days posttreatment, root, stem, and leaf colonization was assessed quantitatively (CFU) using Luria Bertani agar medium (Fig. 1). Within 5 days of bacterial treatment, there was a strong colonization of the rhizosphere by PTA-CT2 (Fig. 1, unsterilized roots). To substantiate that colonization was restricted or not to the root surface, we compared the extent of colonization between sterilized and unsterilized roots, after grinding them in phosphatebuffered saline (PBS) medium. As shown in Figure 1, within 5 days of treatment, $9.2 \times 10^{6} \mathrm{CFU}$ and $7.54 \times 10^{8} \mathrm{CFU}$ per gram of fresh weight were recovered from surface-sterilized and unsterilized roots, respectively (Fig. 1). Hence, we found 
approximately 82 times more bacteria in the rhizoplane than in internal root tissues, while no bacteria were detected in the above-ground parts (data not shown), indicating that PTA-CT2 colonized mainly the root surface and, to a lesser extent, the endosphere. This also supports PTA-CT2-mediated ISR as a primary mode of conferring grapevine protection against $B$. cinerea.

\section{PTA-CT2 induces phenotypic changes.}

To determine a plausible interrelationship between root colonization by PTA-CT2 and the grapevine plant reactions at the phenotypic level, macroscopic analyses of roots and shoots were performed after inoculation. Within 5 days, plants inoculated with PTA-CT2 present stronger stems with a reddish color compared with control stems (Fig. 2B and A, respectively). In the same conditions, roots became brown and lost their stiffness (Fig. 2C), whereas in control plants roots had normal color (Fig. 2D). The reddish color observed in response to PTA-CT2 correlated with elevation of anthocyanin content in both leaves and stems (Fig. 3). The total amount of anthocyanin in PTA-CT2-treated plants was markedly higher in stemsthan in leaves (Fig. 3B and A, respectively). Anthocyanin content also increased in $B$. cinereainfected plants and its level was maintained high in both leaves and stems of bacterized plants after pathogen infection. The
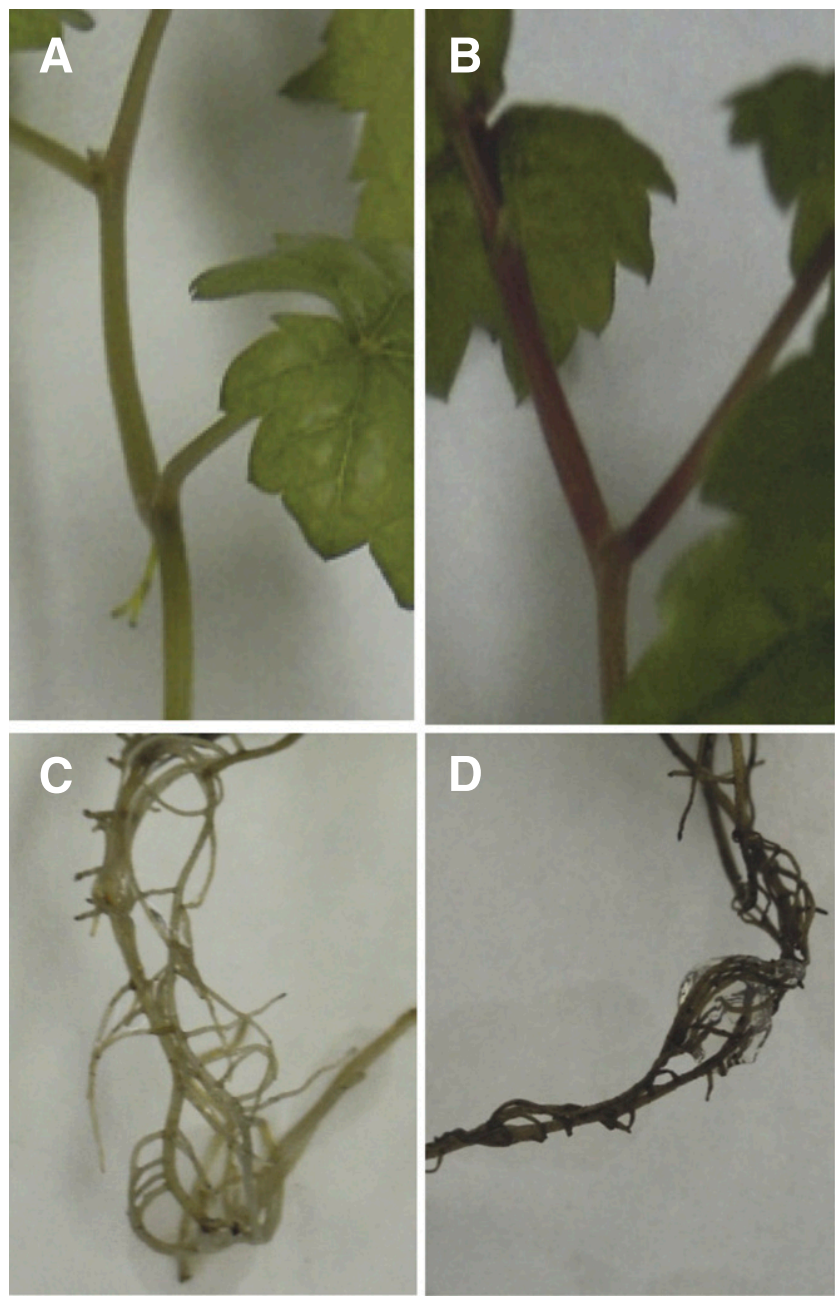

Fig. 2. Pseudomonas PTA-CT2 induces phenotypic changes in grapevine plants. A and $\mathbf{C}$, Representative photographs depict macroscopic changes on stems and roots from control plants or $\mathbf{B}$ and $\mathbf{D}$, plants treated at the root level with PTA-CT2 at $2 \times 10^{7} \mathrm{CFU} \mathrm{m}{ }^{-1}$. Images were taken at 5 days posttreatment. Stems (B) and roots (D) of root-treated plants with PTA-CT2 are compared with stems (A) and roots (C) of control plants. induced browning in roots also prompted us to investigate the relationship with a possible induction of cell death by PTA-CT2. For this purpose, roots from control and PTA-CT2-treated plants were stained with Evan's blue to monitor cell death. Only small patches of blue staining were observed in the roots of control plants (Fig. 4A and C), while Evan's blue staining tagged large portions of the roots from PTA-CT2-treated plants, albeit some browned area remained unstained (Fig. 4B and D). This suggests that PTA-CT2 triggers some induction of cell death in roots.

\section{PTA-CT2 triggers differential defense gene expression in roots and leaves.}

To investigate the local and systemic response of grapevine to PTA-CT2 root colonization, various defense responses were followed in roots and leaves at different time points and were compared simultaneously. The expression pattern of 21 defenserelated genes selected from four different functional groups was analyzed by real-time quantitative reverse transcription polymerase chain reaction (RT-PCR) using specific primers (Supplementary Table S1) and EF1 $\alpha$ and 60RSP genes as internal standards. In control roots and leaves, transcript levels of the different genes were always very low during the experimental period (Supplementary Figs. S1, S2, and S3). However, we showed that most of the targeted genes were transiently upregulated in local and systemic tissues during PAT-CT2-grapevine interaction (Fig. 5). The expression level of three genes encoding transcription factors (TFs) JAZ9 (JA Zim domain) and ERF1 (ethylene response factor), which integrate JA and ET signaling (Lorenzo and Solano 2005; Zhang et al. 2012), and NAC1 (for NAM no apical meristem, ATAF1/2 A. thaliana transcription activation factor, and CUC2 cupshaped

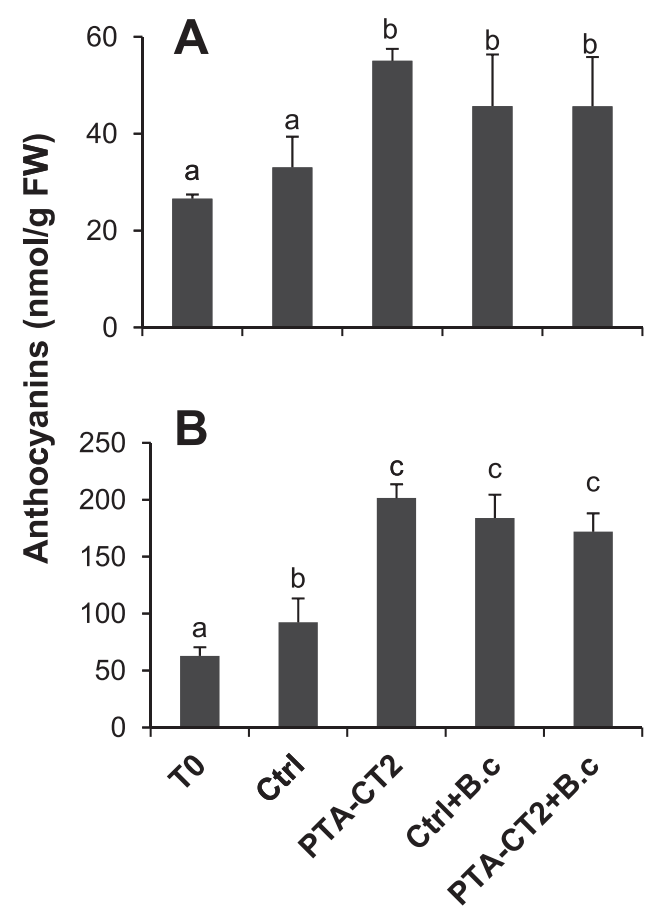

Fig. 3. Anthocyanin accumulation in grapevine plants during PTA-CT2 treatment and after Botrytis cinerea challenge. A, Anthocyanin content was measured in leaves and B, stems at time zero (T0), after 5 days of control (Ctrl) and bacterized (PTA-CT2) plants and $12 \mathrm{~h}$ after $B$. cinerea infection (Ctrl+B.c and PTA-CT2+B.c). Plants were inoculated with B. cinerea after 5 days of root treatment with PTA-CT2 at $2 \times 10^{7} \mathrm{CFU} \mathrm{ml}{ }^{-1}$. Conidia of $B$. cinerea were sprayed at $1 \times 10^{6}$ conidia ml ${ }^{-1}$ on leaves of PTA-CT2-treated and untreated plantlets. Data are means from two independent experiments in triplicate. Vertical bars indicate standard errors $(n=9)$ and different letters indicate statistically significant differences (analysis of variance, $P<0.01)$ 
cotyledon), which integrates SA signaling (Le Hénanff et al. 2013), was upregulated in both roots and leaves by PTA-CT2 relative to controls (Fig. 5). In roots, PTA-CT2 slightly enhanced both JAZ9 and NAC1 transcript levels as early as $1 \mathrm{~h}$ postbacterization (hpb), and the highest expression was reached at $6 \mathrm{hpb}$ (Fig. 5). In leaves, both TFs were transiently induced but later than in roots; their transcript level peaked between 12 and $24 \mathrm{hpb}$ (Fig. 5). ERFl expression was strongly and simultaneously upregulated in roots and leaves with a maximum at $12 \mathrm{hpb}$. These analyses indicated that TFs might be involved in the initiation of the PTA-CT2-mediated immune system both locally and systemically.

The induction of the HSR gene, a known marker for hypersensitive response (HR), was also performed. It was revealed that the expression of the HSR gene was transiently upregulated in both roots and leaves of bacterized plants (Fig. 5). The expression being maximal at $24 \mathrm{~h}$ postinfection (hpi), it reached 20- and 10-fold in leaves and roots, respectively, compared with controls. This is consistent with the localized HR-like cell death induced by PTA-CT2 in roots.

We further monitored the expression of genes encoding a phenylalanine ammonia lyase $(P A L)$, which catalyzes the first step of the phenylpropanoid pathway (MacDonald and D'Cunha 2007), a stilbene synthase (STS) responsible for the synthesis of resveratrol, a 9-lipoxygenase ( $L O X 9$ ) involved in the synthesis of oxylipins (Vellosillo et al. 2007) and an ACC synthase (ACCsyn) which catalyzes the synthesis of ACC, as a precursor of ET (Sauter et al. 2013). PAL, STS, LOX9, and ACCsyn transcripts were transiently upregulated at once in both roots and leaves, peaking at $12 \mathrm{hpb}$. Their expression returned to its initial level as soon as $48 \mathrm{hpb}$ (Fig. 5). The transcriptional regulation of two genes encoding glutathione- $S$-transferase (GST1 and GST2) was also monitored. GSTs participate in the detoxification process by conjugating glutathione to electrophilic compounds (Conn et al. 2008). Recent works in grapevine reported that GST1 and GST2 were upregulated in anthocyanin-producing conditions and that GST1 was involved in anthocyanin transport (Conn et al. 2008). Here, we showed that GST1 followed a biphasic expression pattern in roots of rhizo-inoculated plants and peaked at 6 and $72 \mathrm{hpb}$ (Fig. 5), while GST2 was transiently induced with a maximum at $6 \mathrm{hpb}$. In leaves, the steady-state expression level of GST1 was substantially elevated at $12 \mathrm{hpb}$ and remained high thereafter (Fig. 5). GST2 transcripts showed a similar trend but with a lower expression level.

The expression patterns for the anthocyanin biosynthetic genes encoding chalcone synthase (CHS1 and $C H S 2)$, chalcone isomerase $(C H I)$, leucoanthocyanidin dioxygenase $(L A N D)$, and anthocyanidin reductase $(A N R)$ were also investigated in grapevine leaves and roots during PTA-CT2 treatment. In roots, $C H S 2$ and $\mathrm{CHI}$ were slightly and transiently expressed, whereas expression of $C H S 1$ was very low and even decreased during the early hours of interaction with PTA-CT2. Expression of LAND and $A N R$ was very low but increased progressively in roots after PTA-CT2 inoculation. However, there was a strong increase in gene expression in the leaves at 4 and 5 days after PTA-CT2 inoculation. Expression of $L A N D$ and $A N R$ showed similar patterns as $\mathrm{CHS}$ and $\mathrm{CHI}$ in the leaves.

We also focused on the expression pattern of some $P R$ genes that are reliable defense markers in grapevine, such as $P R 1$, a marker of the SA pathway, $P R 2$ encoding a $\beta$-1,3-glucanase, $P R 3-4 c$ - and PR3-4d-encoding chitinases, PR5-5 and PR5-3, two thaumatine-like, and $P R 6$, a serine protease inhibitor. Except for $P R 1$, all the $P R$ genes were upregulated in both roots and leaves in response to PTA-CT2. Over the 5 days of the experiment, no transcript of $P R l$ was detected in roots of bacterized or control plants. In leaves, $P R I$ expression weakly fluctuated, peaking at 6 and 72 hpb. However, a biphasic expression pattern was observed in roots for $P R 2, P R 3-4 c, P R 3-$ $4 d$, and $P R 6$, which peaked first at $24 \mathrm{hpb}$ and, then, between 72 and $96 \mathrm{hpb}$. In leaves, these genes were transiently induced between 12 and $48 \mathrm{hpb}$. The two PR5 genes were differentially expressed depending on plant organ. In roots, PR5-5 was markedly expressed as soon as $12 \mathrm{hpb}$ and remained highly upregulated over the 5 days postbacterization (dpb), while PR53 expression was only slightly enhanced. Conversely, in leaves, PR5-3 was strongly upregulated and followed a biphasic pattern

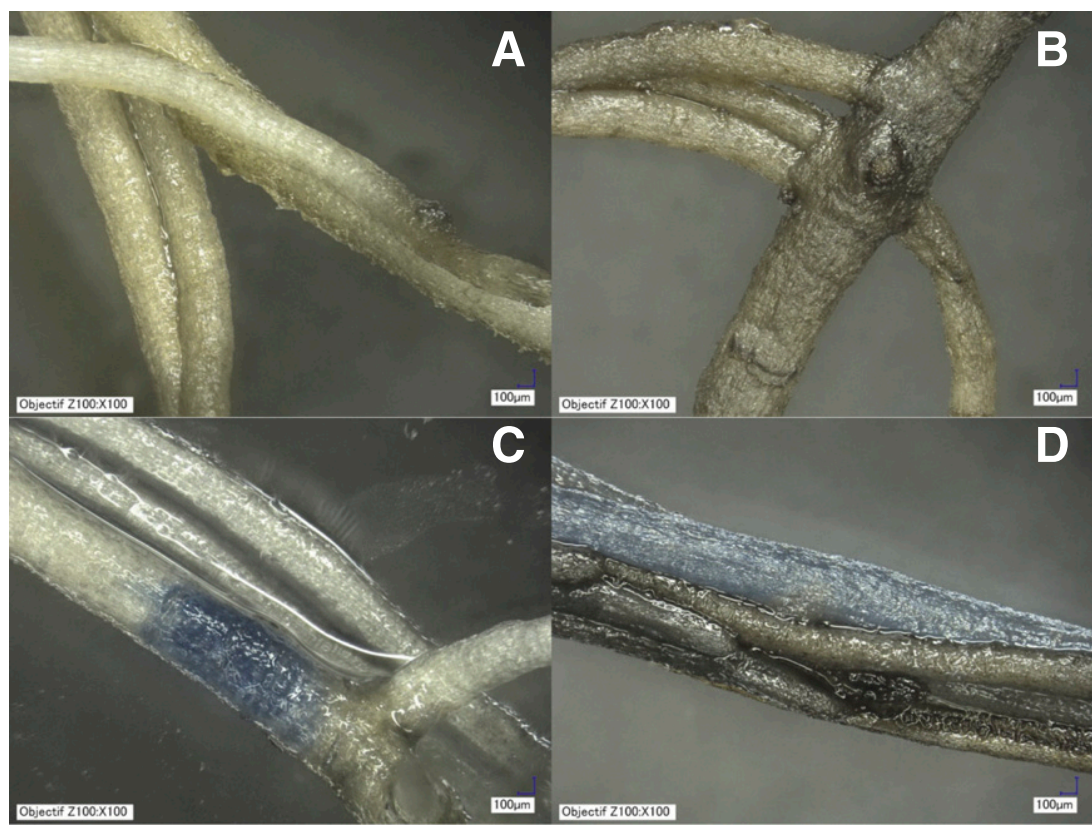

Fig. 4. Cell death in roots of grapevine plants after treatment with PTA-CT2. Plantlets were treated or not at the root level with PTA-CT2 at $2 \times 10^{7} \mathrm{CFU}^{-1}$ for 5 days, and roots were stained or not with $0.1 \%$ Evans blue solution. A, Control without Evans blue staining, B, PTA-CT2-treated without Evans blue staining, C, control roots stained with Evans blue, and D, PTA-CT2-treated roots stained with Evans blue. Photographs were acquired with the VHX-2000 three-dimensional $(3 \mathrm{D})$ microscope $(\mathrm{Z} 100 \times 100)$ and integration of images was performed with the 3D profile VHX-H3M software. 
and $P R$ 5-5 was only weakly upregulated between 6 and $24 \mathrm{hpb}$. These results indicate that $P R$ genes (excepted $P R I$ ) and TFs responded more quickly in roots than in leaves and suggest that different signaling pathways might be critical in regulating PTACT2-mediated immune response at both the above- and belowground level of grapevine plants.

\section{Phytoalexin production drops in roots but increases in leaves during the plant-bacterium interaction.}

The main phytoalexins that accumulate in grapevine after infection by fungi or bacteria are stilbenes including resveratrol (trans-3,4',5-trihydroxystilbene), its dehydrodimer $\varepsilon$-viniferin, as well as its glycoside form, piceid. To further test the link between PTA-CT2-induced expression of PAL and STS genes and phytoalexin production, we performed a timecourse analysis comparing patterns of resveratrol and its derivatives piceid and $\varepsilon$-viniferin in local and systemic tissues. Accumulation of stilbenes is frequently associated with an enhanced grapevine resistance to both biotrophic and necrotrophic pathogens (Chong et al. 2009). As shown in Figure 6A, B and C, at time 0, phytoalexin level is barely detectable in leaves while it is constitutively elevated in roots, with about 13,60 , and $50 \mu \mathrm{g}$ per gram of fresh weight $(\mathrm{FW})$ of resveratrol, piceid, and $\varepsilon$-viniferin, respectively (Fig. 6D, E, and F). These initial values are consistent with the high expression of PAL and STS in roots compared with leaves (data not shown). Over the 5 days of the experiment, piceid and resveratrol content slightly decreased in roots of control plants, whereas $\varepsilon$-viniferin content increased moderately (Fig. 6D, E, and F). Concomitantly, in leaves of control plants, the basal level of phytoalexin remained unchanged (Fig. 6A, B, and C). In roots colonized by PTA-CT2, phytoalexin content drastically dropped; resveratrol and piceid levels decreased by about $90 \%$ of their initial values and $\varepsilon$-viniferin content decreased by $60 \%$ (Fig. 6D, E, and F). In contrast, in leaves of PTACT2-treated plants, a sharp increase of phytoalexin level was observed during the first period of interaction. Resveratrol and $\varepsilon$-viniferin content reached a high level at $3 \mathrm{dpb}$ before declining at $5 \mathrm{dpb}$ (Fig. 6B and C), while piceid content increased to a greater extent at $3 \mathrm{dpb}$, after which it remained significantly elevated in response to PTA-CT2 (Fig. 6A). Although phytoalexin biosynthesis appears to be active both locally and systemically in response to PTA-CT2, stilbene patterns followed opposite trends in roots and leaves. Their level decreased dramatically in the former and increased in the latter. By the end of the experiment, no phytoalexin was detected in the culture medium in which grapevine roots were dipped (data not shown). This suggests that stilbenes might be remobilized or transported, or both, from roots to leaves but not through exudates during plant-bacterium interaction.

\section{PTA-CT2 induces systemic resistance in grapevine against $B$. cinerea.}

Bioassays performed on detached leaves, from control and root-bacterized grapevine plants, inoculated with drops of $B$. cinerea conidia showed that PTA-CT2 significantly reduced disease incidence caused by the pathogen. Within $48 \mathrm{hpi}$, PTACT2 reduced disease development by approximately $60 \%$ (Fig. 7A). Consistent with these macroscopic observations, spraying leaves of intact plants with $B$. cinerea conidia also resulted in a significant reduction of pathogen development in plants treated

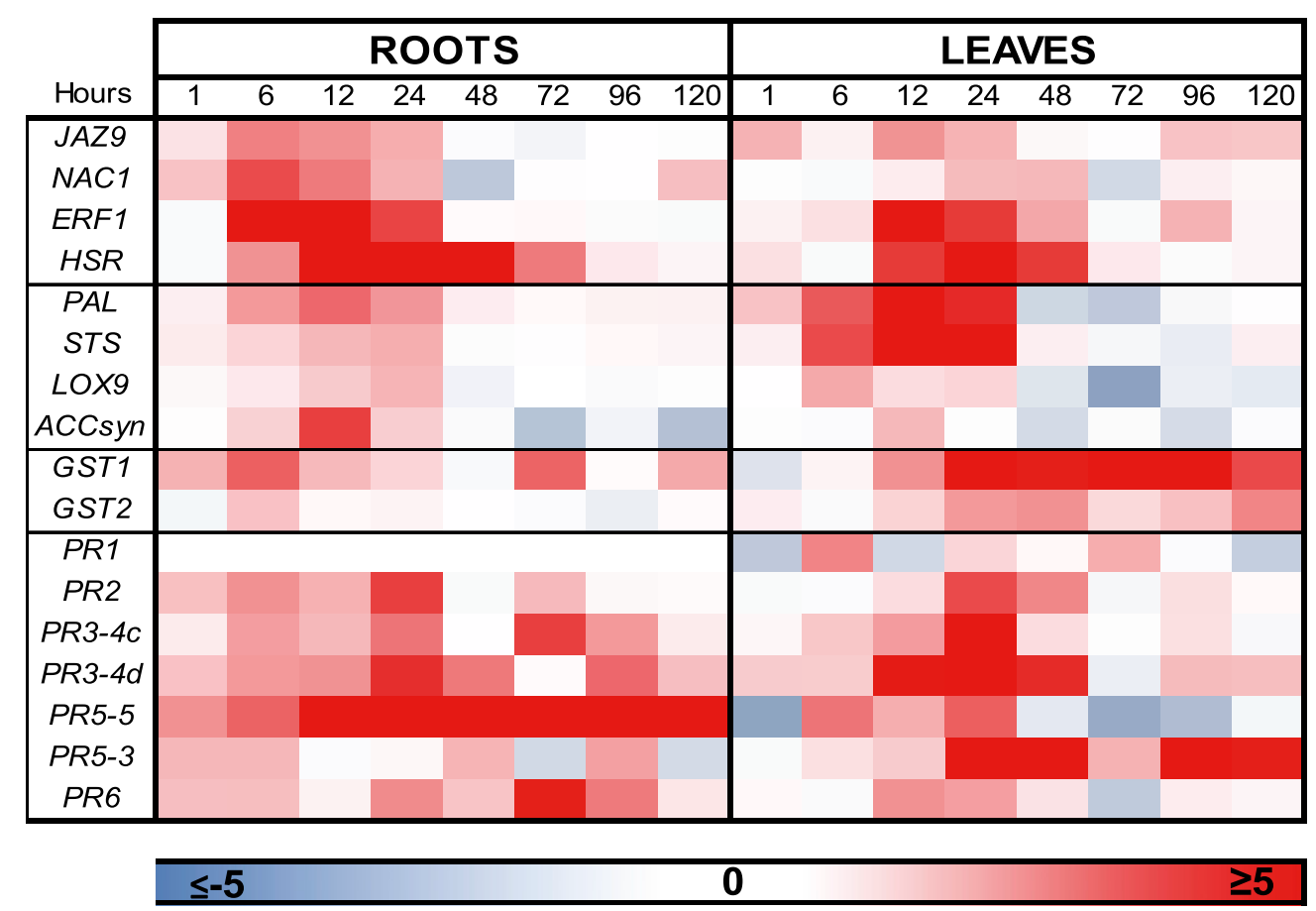

Fig. 5. Pseudomonas fluorescens PTA-CT2 induces differential expression of defense-related genes in leaves and roots of grapevine plants. Plantlets were treated at the root level with PTA-CT2 at $2 \times 10^{7} \mathrm{CFU} \mathrm{ml}^{-1}$. Analyses were performed by quantitative real-time polymerase chain reaction. The fold induction values were normalized to the reference genes EFl $\alpha$ and $60 R S P$ as internal controls and to leaves or roots of untreated plantlets as the control sample (1× expression level). Results are means from at least three independent experiments. Each column represents the time in hours postbacterization and each row represents one gene. A tree color scale was used to show expression of each gene in bacterized compared with control plantlets in roots (left) and leaves (right). Red shades indicate overexpression and deep red corresponds to an induction factor of 5 or more; white represents the basal expression level and signifies that the expression in bacterized-plants is not different from the control samples; blue shades symbolize repression and dark blue corresponds to a fivefold repression. $J A Z 9, E R F 1$, and $N A C 1$ are transcription factors; $H S R=$ hypersensitive-related; $P A L=$ phenylalanine ammonia-lyase; $S T S=$ stilbene synthase; GST1 and GST2 = glutathione $S$-transferase 1 and 2, respectively; $L O X 9=$ lipoxygenase $9 ; A C C s y n=1$-aminocyclopropane-1-carboxylic acid-synthase; $P R-1=$ pathogenesis-related protein $1 ; P R 2=\beta-1,3$-glucanase $; P R 3-4 C$ and $P R 3-4 D=$ acidic class IV chitinases; $P R 5-5=$ pathogenesis-related protein 5; $P R 5-3=$ thaumatine-like 3 , and $P R 6=$ serine proteinase inhibitor. No amplification signal was detected for $P R-1$ in roots. 
with PTA-CT2 (Fig. 7B; Supplementary Fig. S4). RT-PCR analysis of constitutive Actin gene of $B$. cinerea in leaves of intact plants showed two distinct phases of fungal development (Fig. 7C). Expression of Actin gene increased by approximately 600-fold at 6 hpi and remained similar in control and PTA-CT2treated plants until 9 hpi (Fig. 7D). Thereafter, Actin transcript level of $B$. cinerea increased by approximately five times in leaves of control plants compared with those of PTA-CT2treated ones (Fig. 7C), supporting the idea that root-colonizing $P$. fluorescens PTA-CT2 induced ISR against the necrotrophic pathogen $B$. cinerea.

PTA-CT2 enhances phytoalexin accumulation but not the expression of most of the defense genes in leaves after pathogen infection.

Beneficial rhizobacteria can induce ISR by priming aboveground plant parts for enhanced defense against pathogens (Conrath et al. 2002; Verhagen et al. 2004). To investigate the mechanisms involved in PTA-CT2-mediated ISR, we examined transcript levels of various defense marker genes upon $B$. cinerea infection. After 5 days of bacterial treatment, leaves were inoculated by spraying them with $B$. cinerea conidia. As shown in a previous study using detached leaves (Verhagen et al. 2011), we demonstrated that PTA-CT2 also primed grapevine plants for enhanced phytoalexin accumulation after spraying leaves of the whole plant with $B$. cinerea. Both resveratrol and piceid levels increased faster and stronger in the $B$. cinerea-infected leaves of PTA-CT2-treated plants than in control plants. By $48 \mathrm{~h}$ of fungal challenge, piceid and resveratrol amounts in ISR-expressing leaves were 2.5- and 1.5-fold higher than in control leaves, respectively (Fig. 8A and B). Meanwhile, $\varepsilon$-viniferin content gradually increased and reached a strong level in challenged leaves of ISR-expressing plants compared with control (Fig. 8C). These results highlight that PTA-CT2-mediated ISR is tightly associated to priming phytoalexin production in leaves after B. cinerea infection.

The previous results prompted us to unravel the molecular mechanisms governing the expression of ISR in grapevine. To this end, we monitored the expression of the same set of defense-related genes analyzed upon root colonization by PTACT2. We specifically focused on the transcriptional changes over the first $9 \mathrm{hpi}$, when $B$. cinerea displayed a comparable development in control and PTA-CT2-treated plants. RT-PCR analyses showed that all targeted genes were upregulated in control and bacterized plants after B. cinerea infection (Fig. 9; Supplementary Fig. S5). The GST1 gene was the only exception, whose level of expression was upregulated upon pathogen infection in PTA-CT2-treated plants. The expression of the anthocyanin biosynthetic genes (CHS1, CHS2, CHI, LAND, and $A N R$ ) was maintained at high levels in the leaves of bacterized plants and was correlated with elevation of anthocyanin contents after challenge with $B$. cinerea (Fig. 3). The expression of ACCsyn, GST2, PR1, and PR6 did not show any consistent difference between nontreated and PTA-CT2-treated plants. More surprisingly, most of genes, including JAZ9, NAC1, ERF1, HSR, PAL, STS, LOX9, PR2, PR3-4c, PR3-4d, $P R 5-3$ and PR5-5, showed a lower expression in the leaves of ISR-expressing plants compared with untreated plants (Fig. 9).

\section{DISCUSSION}

We previously demonstrated that $P$. fluorescens PTA-CT2 was able to induce defense responses in grapevine leaves or berries and conferred protection against Botrytis cinerea (Magnin-Robert et al. 2007; Trotel-Aziz et al. 2008; Verhagen et al. 2011). Besides the beneficial effects of the PTA-CT2 on grapevine resistance, no studies have reported partial or global transcriptional changes at the local or systemic level upon PTA-CT2
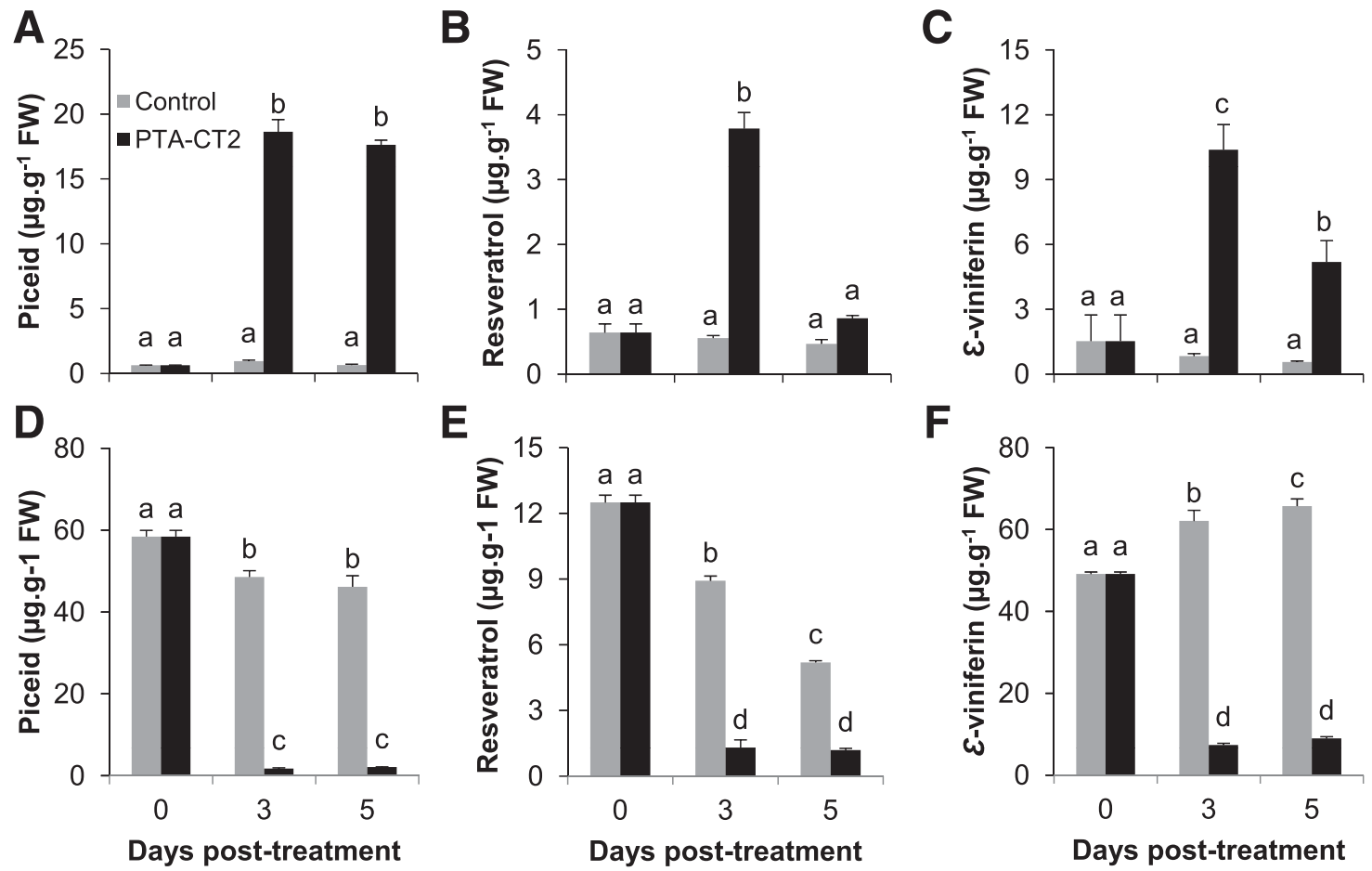

Fig. 6. Pseudomonas fluorescens PTA-CT2 induces opposite changes in phytoalexin levels in grapevine leaves and roots. A and D, Piceid, B and E, resveratrol, and $\mathbf{C}$ and $\mathbf{F}$, $\varepsilon$-viniferin content in leaves $(\mathrm{A}, \mathrm{B}, \mathrm{C})$ and roots $(\mathrm{D}, \mathrm{E}, \mathrm{F})$ of grapevine plants treated at the root level with PTA-CT2 at $2 \times 10^{7} \mathrm{CFU} \mathrm{ml}^{-1}$ (black) or in untreated plants (gray). The results are means for three independent experiments, each with six technical replicates, and are expressed in micrograms of phytoalexin per gram of fresh weight. Vertical bars indicate standard errors $(n=18)$ and different letters indicate statistically significant differences between treatments (analysis of variance test, $P<0.05$ ). 
treatment or after pathogen challenge. Here, we provide information about the difference in local and systemic PTA-CT2induced immune responses, as well as putative mechanisms involved in PTA-CT2-induced ISR against $B$. cinerea. We demonstrated that PTA-CT2 triggers an immune response in grapevine at the full-plant scale as most of defense genes were upregulated and secondary metabolism was dramatically affected both locally and systemically. Our results also revealed that PTA-CT2 induced ISR against $B$. cinerea by priming above-ground plant parts for enhanced stilbene accumulation and GST1 expression, but the expression of most defenserelated genes, including $H S R$, was reduced after $B$. cinerea infection in systemic tissues of PTA-CT2-treated plants as compared with control plants.

\section{P. fluorescens PTA-CT2 colonizes only grapevine roots but induces differential immune responses in local and systemic tissues.}

Our results clearly demonstrate that PTA-CT2 colonized grapevine roots but not above-ground plant parts and changed the plant phenotype that displayed multiple defense responses. This suggests that one or more systemic signals could be involved in PTA-CT2-induced systemic immune response rather than the bacterium itself. In addition to the severely stunted root system, stems had a more pronounced red shade in response to PTA-CT2 than the nontreated plants. This phenotypic change could be attributed to a weak cell death observed in roots (Fig. 4) and to anthocyanin accumulation in shoots (Fig. 3) that may, therefore, be a general defensive mechanism activated by the bacterium. This is in line with the fact that the expression of $H S R$, a known marker for HR cell death, was transiently upregulated in local and systemic tissues during PTA-CT2-grapevine interaction. The transcriptional responses of grapevine during root colonization by PTA-CT2 displayed distinct patterns of gene expression. We present evidence that roots and leaves respond in distinct manners, probably due to their intrinsic differences in organ function or colonization by the bacterium. A total of 22 defense-related genes, including those with TF functions (JAZ9, $N A C 1$, and ERF1), of secondary metabolism (PAL, STS, LOX9, ACCsyn, GST, CHS, CHI, LAND, ANR), and PR proteins (PRl, $P R 2, P R 3, P R 5$, and $P R 6$ ) were upregulated in leaf tissues, while 20 of them were expressed in roots. However, roots responded more quickly than leaves and some responses, such as ACCsyn, $P R 5-5$, and $P R 6$, were more strongly upregulated in roots than in leaves and vice versa for PAL, STS, GST1, PR3-4D, PR5-3, and the anthocyanin biosynthetic genes (CHS, CHI, LAND, and ANR). These results are consistent with finding that $P$. fluorescens WCS417r and the MAMPs flagellar peptide Flg22 and peptidoglycan trigger a strong tissue-specific response in A. thaliana roots (Millet et al. 2010) but contradict the hypothesis that roots respond weakly or not at all to beneficial microbes or derivative MAMPs to avoid activation of defense responses that could be detrimental to fitness (Van der Ent et al. 2009; Verhagen et al. 2004).

Our results indicated that TFs JAZ9, ERF1, and NAC1 as well as $P R$ genes (except for $P R 1$ ) responded more quickly in roots than in leaves to PTA-CT2, suggesting that these responses might be central components of the induced immune system through different signaling pathways. In A. thaliana, JAZ plays

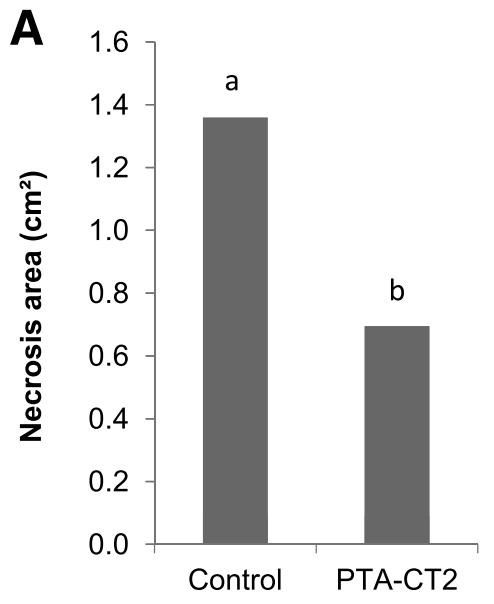

B

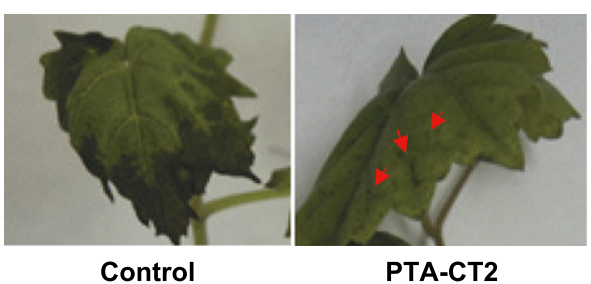

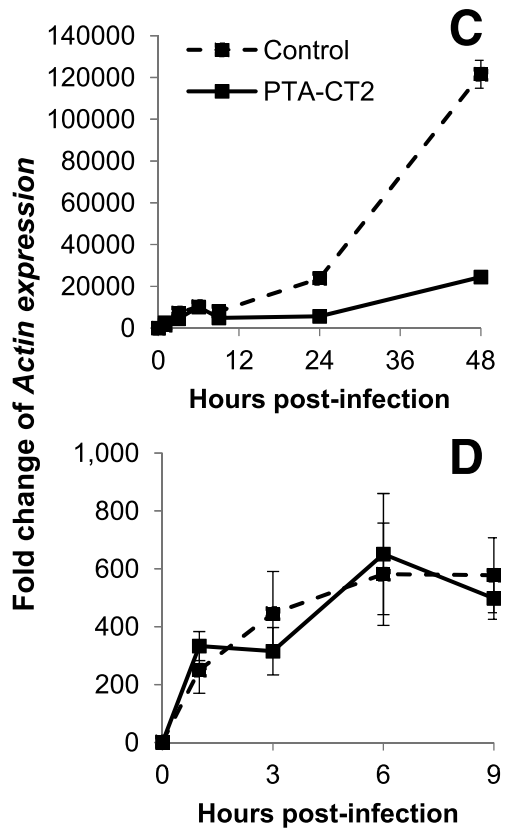

Hours post-infection

Fig. 7. Pseudomonas fluorescens PTA-CT2 induces systemic resistance in grapevine plants against Botrytis cinerea. Plantlets were pretreated at the root level with PTA-CT2 at $2 \times 10^{7} \mathrm{CFU} \mathrm{ml} \mathrm{m}^{-1}$ for 5 days. A, Disease development on detached leaves from control and PTA-CT2-treated plants, $48 \mathrm{~h}$ after challenge with a drop $(10 \mu \mathrm{l})$ of $B$. cinerea conidia at $1 \times 10^{6}$ conidia $\mathrm{ml}^{-1}$. Necrosis surface was acquired with the APS Assess 2.0 software. About 30 leaves were used for each condition in one experiment and the results are means of six independent experiments. An analysis of variance test was performed using R software at $P<$ 0.05. B, Foliar symptoms from control (left) and PTA-CT2-treated (right) plants inoculated with $B$. cinerea by spraying conidia at $1 \times 10^{6}$ conidia ml $^{-1}$ on the leaves of intact plants. Images captured at 3 days postinfection are representative of the results. The red arrows indicate small necrotic lesions caused by $B$. cinerea on the leaves of PTA-CT2-treated plants. C and D, Fold change of Actin gene of B. cinerea in leaves of bacterized (full lines) and control (dotted lines) plantlets over 48 and $9 \mathrm{~h}$ (B and C, respectively) of $B$. cinerea infection. Conidial suspensions of $B$. cinerea were sprayed at $1 \times 10^{6}$ conidia ml ${ }^{-1}$ on the leaves of intact plants. Analyses were performed by quantitative real-time polymerase chain reaction. The reference genes EF $1 \alpha$ and $60 R S P$ were used as internal controls and leaves of infected plantlets at zero time correspond to the reference sample ( $1 \times$ expression level). The $0 \mathrm{~h}$ postinfection corresponds to 5 days of treatment with $P$. fluorescens PTA-CT2. The results presented are means from three independent experiments. Vertical bars indicate standard errors $(n=9)$. 
a role in the control of the JA signaling pathway (Chini et al. 2007; Thines et al. 2007). Similarly, in grapevine, JAZ9 was responsive to JA but not to SA or ET (Zhang et al. 2012), while $N A C 1$ was regulated by different phytohormones including SA (Le Hénanff et al. 2013; Zhu et al. 2012). ERF1 and JAZ9 have been also described as integrators of the JA and ET signaling in A. thaliana that regulate a number of defense-related genes (Lorenzo and Solano 2005; Zhang et al. 2012). This pool of genes might be regulated by an early JA or ET signal initiated in roots upon PTA-CT2 perception, and signal can then be transduced to above-ground parts, which can explain the delay between upregulated gene expression in roots and leaves. Activation of the JA and ET pathways may be a common strategy to affect grapevine immunity in both root and leaf tissues. This was supported by enhanced expression of LOX 9 and ACCsyn as key elements of the oxylipin and ET synthesis pathways, respectively (in this study), and induced lipoxygenase activity in grapevine leaves by PTA-CT2 (Trotel-Aziz et al. 2008). Furthermore, we showed that PTA-CT2 is able to induce the
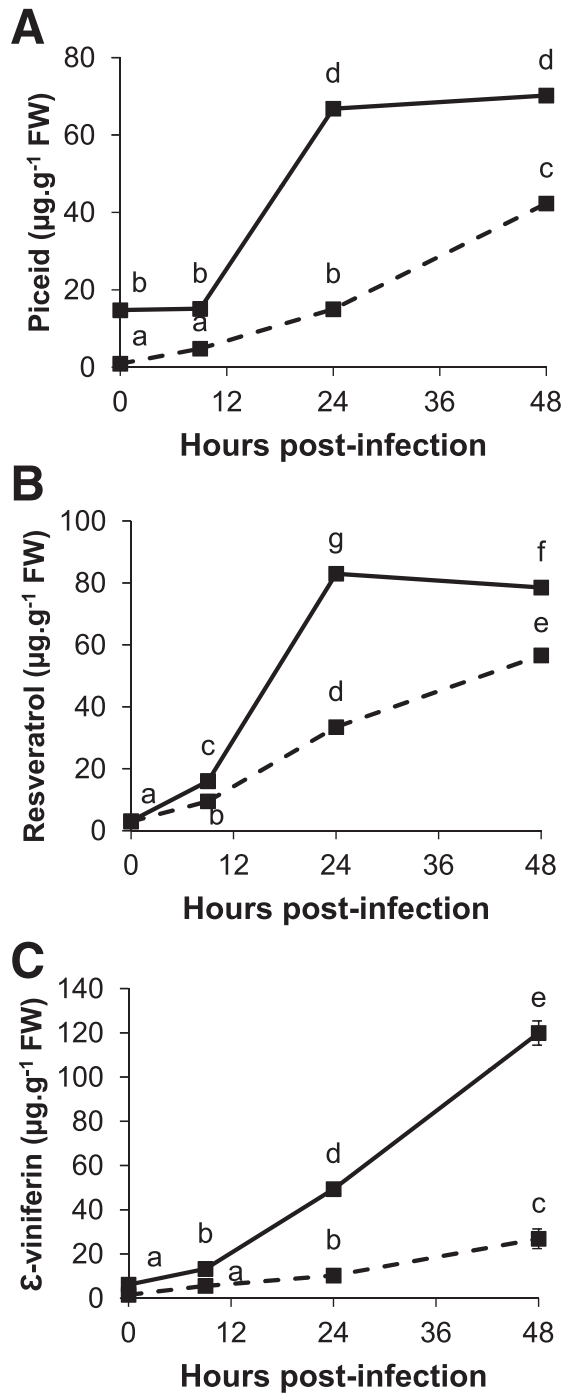

Fig. 8. Priming of phytoalexin accumulation in leaves of PTA-CT2-treated (full lines) and control (dotted lines) plantlets over $48 \mathrm{~h}$ of Botrytis cinerea infection. Plantlets were infected after 5 days of root treatment with or without PTA-CT2 at $2 \times 10^{7} \mathrm{CFU} \mathrm{ml}^{-1}$. Conidia of $B$. cinerea were sprayed at $1 \times 10^{6}$ conidia $\mathrm{ml}^{-1}$ on the aerial parts of plantlets. Results are means of three independent experiments, each with six technical replicates. Vertical bars indicate standard errors $(n=18)$ and different letters indicate statistically significant differences between treatments (analysis of variance test, $P<0.05$ ). expression of $P R-1, P R-2, P R-3$, and $P R-5$ genes, which were found to be specifically induced by SA or its synthetic analog benzothiadiazole (BTH) in grapevine (Dufour et al. 2013; Gauthier et al. 2014). The expression of $P R-6$ as a JA- or ETdependent response was also responsive to various MAMPs and beneficial microorganisms in grapevine (Aziz et al. 2003; Bordiec et al. 2011; Chong et al. 2009). Similarly, GST1 coding for a glutathione- $S$-transferase was upregulated as soon as $1 \mathrm{hpb}$ in roots and shortly later in leaves. The same gene, which is involved in the redox status of the plant, was also induced by BTH in grapevine leaves (Dufour et al. 2013). Although PRI was not induced in roots, taken together, our data suggest that both JA- or ET-dependent and SA-dependent pathways might be

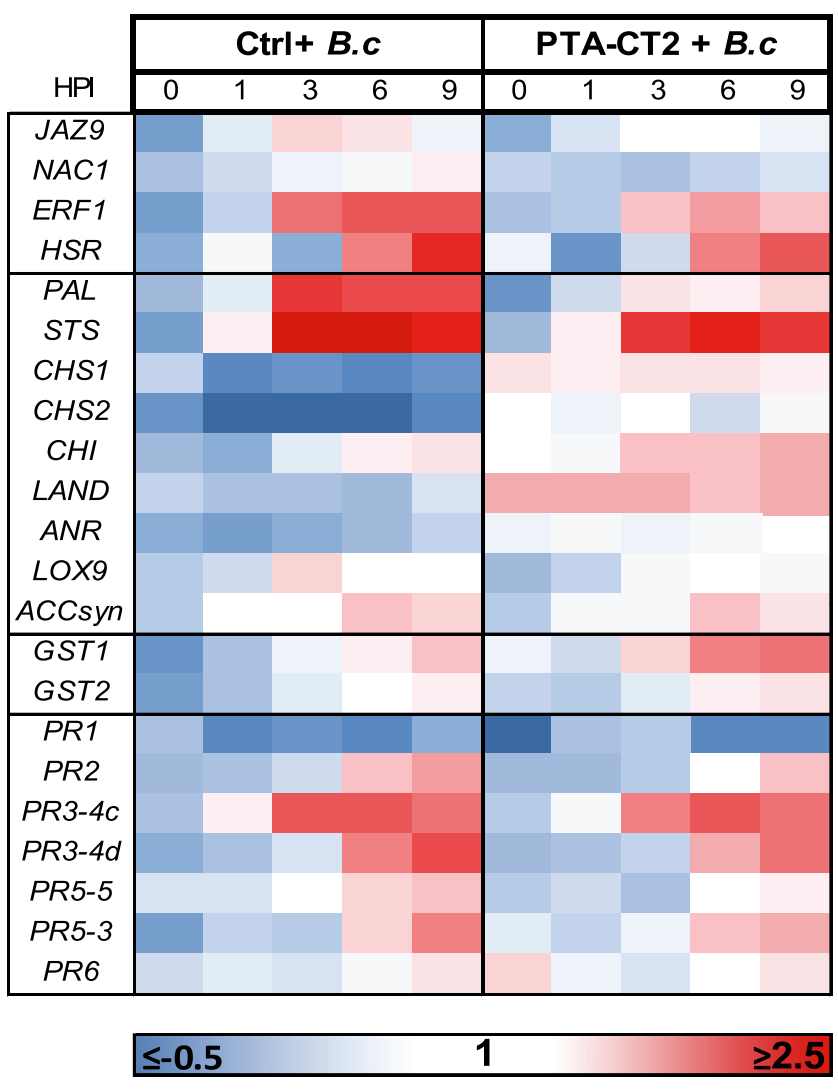

Fig. 9. Transcript levels of defense-related genes in leaves of control and PTACT2-treated plantlets over $9 \mathrm{~h}$ of Botrytis cinerea infection. Plantlets were infected with $B$. cinerea after 5 days of root treatment with or without PTA-CT2 at $2 \times 10^{7} \mathrm{CFU} \mathrm{ml}^{-1}$. Conidia of $B$. cinerea were sprayed at $1 \times 10^{6} \mathrm{conidia} \mathrm{ml}^{-1}$ on leaves of control $(\mathrm{Ctrl}+$ B.c) and PTA-CT2-treated (PTA-CT2+B.c) plants. Analyses were performed by real-time polymerase chain reaction. The reference genes $E F 1 \alpha$ and $60 R S P$ were used as internal controls and leaves of infected plantlets at time zero correspond to the reference sample ( $1 \times$ expression level). The $0 \mathrm{~h}$ postinfection (hpi) on the graphics correspond to 5 days of treatment with or without $P$. fluorescens PTA-CT2. The results presented are means from three independent experiments. Each column represents the time in hours postinoculation and each row represents one gene. A tree color scale was used to show fold induction of each gene (log transformed) in control (left) and PTACT2-treated (right) plants. Red shades indicate overexpression and deep red corresponds to $\log$ (induction factor) of 2.5 or more, white represents the basal induction level, blue symbolizes repression, and dark blue corresponds to log (induction factor) equal or less than -0.5. JAZ9, ERF1, and NAC1 are transcription factors; $H S R=$ hypersensitive-related; $P A L=$ phenylalanine ammonia-lyase; $S T S=$ stilbene synthase; $C H S 1$ and $C H S 2=$ chalcone synthase 1 and 2, respectively; $C H I=$ chalcone isomerase; $L A N D=$ leucoanthocyanidin dioxygenase; and $A N R=$ anthocyanidin reductase $; L O X 9=$ lipoxygenase $9 ; A C C s y n=$ 1-aminocyclopropane-1-carboxylic acid-synthase; GST1 and GST2 = glutathione $S$-transferase 1 and 2 , respectively; $P R-1=$ pathogenesisrelated protein $1 ; P R 2=\beta$-1,3-glucanase; $P R 3-4 C$ and $P R 3-4 D=$ acidic class IV chitinases; $P R 5-5=$ pathogenesis-related protein $5 ; P R 5-3=$ thaumatine-like 3 , and $P R 6=$ serine proteinase inhibitor. 
involved in the PTA-CT2-mediated immune response in both leaves and roots. This is in accordance with some reports indicating that SA-dependent signaling is crucial in interactions of plant roots with nonpathogenic microbes (van de Mortel et al. 2012) but contradicts others considering rhizobacteria-induced immunity often SA-independent and not associated with major changes in defense-related gene expression (Van der Ent et al. 2009).

PAL and STS as the first enzymes of the phenylpropanoid pathway can lead to the synthesis of many secondary compounds, including flavonoids, lignin, and phytoalexins (Aziz et al. 2003; MacDonald and D'Cunha 2007). Some of these compounds might be responsible for the induced phenotypic change by PTA-CT2. Despite the expression of PAL and STS genes in both leaves and roots, the overall phytoalexin content (resveratrol, $\varepsilon$-viniferin, and piceid) strongly decreased in roots, whereas it simultaneously increased in leaves (Fig. 4). PTACT2 did not induce the secretion of any of these phytoalexins into the medium in which roots were dipped (data not shown). It is tempting to speculate that remobilization or transport, or both, of some stilbenes, such as piceid, could be, at least in part, at the origin of an increase of resveratrol and viniferin in leaves. However, despite understanding of stilbene biosynthesis and regulation, nothing is known about the mechanisms of their remobilization and transport in planta. Due to its glucose moiety, piceid has been proposed as a storage form of resveratrol and is considered as the most polar phytoalexin that can be transported from one organ to another. This is in line with the fact that roots have been proposed to play a role of storage organ for defense compounds ready to be translocated to shoots (Balmer et al. 2013; Erb et al. 2009; Kumar and Bais 2012). Stilbenes have antimicrobial activities and they also accumulated in response to different beneficial bacteria or MAMPs, including the SA analog BTH (Aziz et al. 2006; Dufour et al. 2013; Verhagen et al. 2010). The decreased levels of stilbenic phytoalexin as well as the nonexpression of $P R 1$ by PTA-CT2 in grapevine roots might contribute to stable root colonization by the bacterium. It has been suggested that, in the initial stage of interaction, nonpathogenic microbes are sensitive to SA-regulated defense responses (Doornbos et al. 2011).

\section{ISR-inducing PTA-CT2 upregulates only a few responses but downregulates most of the defense-related genes in leaves after pathogen infection.}

In this study, we showed that PTA-CT2 colonizes roots but is not transported within grapevine plants. Therefore, a likely explanation of PTA-CT2-induced resistance in distal leaf tissues is an ISR. This resistance was confirmed by a significant reduction of necrotic lesions (Verhagen et al. 2011) and the lower expression of Actin gene of B. cinerea in infected leaves of PTA-CT2-treated plants as compared with infected control (this study). The molecular mechanism underpinning PTAinduced ISR in grapevine has not yet been deciphered. Nevertheless, several reports have suggested that most beneficial bacteria induce a primed state in plants (Van der Ent et al. 2009; Verhagen et al. 2010). In this study, we showed that PTA-CT2 pretreatment primed grapevine plants for enhanced phytoalexin accumulation in leaves after $B$. cinerea challenge, which could explain their resistance level to the pathogen (Verhagen et al. 2011). However, the primed phytoalexin level was not correlated with changes in transcript abundance of STS after pathogen infection, supporting the proposal that different STS genes are involved in phytoalexin biosynthesis (Parage et al. 2012). Surprisingly, among the 22 defense-related genes monitored in infected leaves, only GST1 was highly upregulated and the expression of anthocyanin biosynthetic genes was maintained at a high level in the bacterized plants after pathogen infection. The upregulated GST1 expression by PTA-CT2 could bring the plant in an immune-ready state participating in the ISR, probably on account of its connection with the anthocyanin production and their transport in planta (Conn et al. 2008), which are involved in grapevine resistance to $B$. cinerea (Iriti et al. 2004). In A. thaliana, enhanced GST1 mRNA accumulation was associated to the increased phytoalexin camalexine accumulation and to wound-induced resistance against $B$. cinerea (Chassot et al. 2008). The authors suggested that GST might be needed to prevent damages related to phytoalexin toxicity at high concentration. GST1 has been selected as a robust marker for the production of reactive oxygen species (ROS) and as a SA-marker gene in grapevine (Gauthier et al. 2014), suggesting that PTA-CT2-induced ISR could involve the contribution of the SA signaling pathway. However, neither TF genes nor other JA- and ET-regulated genes in grapevine (LOX9, ACCsyn, and $P R 6)$ were upregulated in bacterized plants inoculated with $B$. cinerea, suggesting that the PTA-CT2-induced resistance could differ from the typical JA- or ET-dependent response.

The most striking event is that PTA-CT2 initially elicited plant defense responses but, subsequently, after challenge with $B$. cinerea, the majority of defense-related genes were downregulated. The repressed genes primarily belong to genes with TF function, JAZ9, NACl, and ERF1, those involved in secondary metabolism, PAL, LOX9, and STS, and those encoding PR proteins, such as $P R 2, P R 3$, and $P R 5$. Such downregulation was already observed but not discussed in different plant species expressing a systemic resistance and seemed to depend on the pathogen virulence (Dufour et al. 2013; Mohamed et al. 2007; Stein et al. 2008; van Wees et al. 1999). In our system, the downregulated gene expression could not be due to $B$. cinerea development, since the expression of Actin gene of $B$. cinerea was similar in leaves of control and ISR-expressing plants during the first 9 hpi (Fig. 7C). Our results suggest that ISR is not necessarily associated with upregulation of most defenserelated genes, but the resistance state could involve specific and more effective responses, such as activation of secondary metabolism and reduction of HR-like cell death by beneficial bacteria. Therefore, it is likely that PTA-CT2 may suppress some plant defense responses to enable successful colonization of roots, as described in rhizobia-legume or plant-mycorrhizal fungi symbiosis (Tellström et al. 2007; Zamioudis and Pieterse, 2012). It has been shown that some rhizobial MAMPs play a role in downregulation of transcriptional reprogramming in leguminous hosts (Tellström et al. 2007). PTA-CT2 may also modulate host immune responses by interfering with the ET signaling pathway. Several beneficial microbes have been shown to secrete ACC deaminase, resulting in reduced ET production in the plant. Another plausible scenario is that the bacterium can produce some compounds like phytohormones that can negatively crosscommunicate with the plant signaling pathway and affect the immune response. Any way, how nonsymbiotic beneficial bacterium could suppress the plant immune response remains to be explored.

Overall, our results clearly demonstrated that PTA-CT2 triggers an immune response in grapevine in both roots and leaves. This bacterium induced the expression of defenserelated genes that are responsive to different phytohormones, suggesting that different signaling pathways might be critical in the perception of PTA-CT2 at both local and systemic levels. However, stilbene patterns followed opposite trends in roots and leaves during plant-bacterium interaction, despite activation of their biosynthetic pathway. This suggests that a part of these stilbenes could be transported or remobilized, or both, toward the leaves and that roots could play an important role in the above-ground systemic immune response. Unexpectedly, in B. cinerea-infected leaves, PTA-CT2-mediated ISR was accompanied in a large part by a downregulation of different defense-related genes, including the $H S R$ gene as a marker of 
HR and cell death. However, only phytoalexin accumulation and GST1 expression were increased, while the high level of anthocyanins and expression of their biosynthetic genes were maintained in bacterized plant after infection. This is consistent with the fact that $B$. cinerea, as a necrotrophic fungus, promoted cell death as indicated by the increased expression of the HSR gene in nonbacterized plants. The reduced expression of this gene associated to the accumulation of stilbenes may play a prominent role in plant immune response, then conferring resistance to the necrotrophic pathogen $B$. cinerea. However, one or more mechanisms underlying stilbene remobilization or transport or both and the role of anthocyanin during ISR needs further elucidations.

\section{MATERIALS AND METHODS}

Plant and microbial materials and growth conditions.

Grapevine vitro-plantlets ( $V$. vinifera $\mathrm{L}$. cv. Chardonnay clone 7535) were micropropagated from nodal explants grown on $15 \mathrm{ml}$ of agar-modified Murashige-Skoog (MS) medium (Aziz et al. 2006 ) in $25-\mathrm{mm}$ culture tubes. Plants were grown at $25^{\circ} \mathrm{C}$ with a 16- and 8-h photoperiod. Plantlets (8 weeks old) were transferred from culture tubes to Magenta boxes (Sigma) $24 \mathrm{~h}$ before treatment, for acclimation to the liquid MS medium. Each Magenta box contained four plants and the roots of each plant were immersed individually in $9 \mathrm{ml}$ of sterile liquid MS medium. Experiments were performed in sterile conditions to maintain a gnotobiotic system.

Pseudomonas fluorescens PTA-CT2 (Trotel-Aziz et al. 2008) was precultivated in Luria Bertani liquid medium (100 $\mu \mathrm{l}$ of glycerol stock for $10 \mathrm{ml}$ of culture medium) and was incubated at $26^{\circ} \mathrm{C}$ under shaking at $110 \mathrm{rpm}$ overnight. This preculture was used for a new culture under the same conditions.

Botrytis cinerea 630 was grown in liquid medium for 21 days, under shaking at $160 \mathrm{rpm}$ and $22^{\circ} \mathrm{C}$ under continuous light. The culture was ground for $30 \mathrm{~s}$ in a blender and $5 \mathrm{ml}$ of ground culture were plated on solid tomato agar medium (tomato juice $25 \% \mathrm{vol} / \mathrm{vol}$, agar $2,4 \% \mathrm{vol} / \mathrm{vol}$ ) and were incubated for 10 days at $22^{\circ} \mathrm{C}$ under continuous light for sporulation. Conidia were then collected as described in Aziz et al. (2003).

\section{Bacterial treatment.}

Bacteria were collected in their exponential growth phase (18 $\mathrm{h}$ of culture) by centrifugation at $5,000 \times g$ for $10 \mathrm{~min}$. Pellets were washed once and were resuspended in sterile liquid MS medium. Concentration of the bacterial suspension was estimated by spectrophotometry $(450 \mathrm{~nm})$ and was adjusted to $2 \times 10^{8} \mathrm{CFU} \mathrm{m}{ }^{-1}$ in liquid MS medium. One $\mathrm{ml}$ of bacterial suspension was added to the roots of each plantlet in sterile conditions, to reach a final concentration of $2 \times 10^{7} \mathrm{CFU} \mathrm{ml}{ }^{-1}$. For control plantlets, $1 \mathrm{ml}$ of liquid modified MS medium was added. Bacterized and control plantlets were placed in a growth chamber at $20^{\circ} \mathrm{C}$ with a 16 - and 8 -h photoperiod.

\section{Plant colonization assays.}

Roots treated with $P$. fluorescens PTA-CT2 at $2 \times 10^{7} \mathrm{CFU}$ $\mathrm{ml}^{-1}$ for 5 days were collected and surface-sterilized for $4 \mathrm{~min}$ in $0.8 \%$ bleach, supplemented with $0.1 \%$ of Tween 20 . The roots were then washed three times for $1 \mathrm{~min}$ and one more time for $3 \mathrm{~min}$ in sterile water. Aliquots $(200 \mu \mathrm{l})$ of the last washing water were plated on Luria Bertani agar medium as control for surface-sterilization. Sterilized and washed roots (200 mg) were ground in $1 \mathrm{ml}$ of phosphate buffered saline (PBS) and were incubated for $1 \mathrm{~h}$ on a shaker at $400 \mathrm{rpm}$ at room temperature. The root mixture was diluted to $1 \times 10^{-7}$ and $100 \mu \mathrm{l}$ of each dilution were plated on Luria Bertani agar medium in triplicates and were incubated $24 \mathrm{~h}$ at $26^{\circ} \mathrm{C}$. The number of bacteria was counted and expressed as CFU per gram of FW. The experiment was repeated twice.

\section{Cell death.}

Cell death in roots was assayed after 5 days of control or bacterial treatment. The roots of whole plantlets were immersed in a solution of $0.1 \%$ Evan's blue (Sigma). This dye specifically accumulates in dead cells, whereas it is actively excluded from living cells. After $15 \mathrm{~min}$ at room temperature, roots were washed extensively in distilled water to exclude unbound dyes. Pictures were then taken with the VHX-2000 three-dimensional (3D) microscope $(\mathrm{Z} 100 \times 100)$ and integration was performed with the 3D profile VHX-H3M software.

\section{Fungal infection and disease evaluation.}

Conidia were collected by scraping and resuspending solid culture in $8 \mathrm{ml}$ of growth culture medium and shaking overnight, at $160 \mathrm{rpm}$ at $22^{\circ} \mathrm{C}$ under continuous light. Conidial concentration was determined by direct counting of spores with a Malassez counting chamber, adjusted with culture medium at $1 \times 10^{6}$ conidia $\mathrm{ml}^{-1}$.

To assess plant protection levels, detached leaves of 5 days bacterized or control plantlets were maintained in petri dishes, with the upper face in contact with humidified Whatman paper disc. They were infected with a $10-\mu l$ drop of conidial suspension at $1 \times 10^{6}$ conidia $\mathrm{ml}^{-1}$. Inoculated leaves were placed in a growth chamber at $20^{\circ} \mathrm{C}$ with a 16- and 8-h photoperiod. Necrotic lesion was measured 48 hpi with APS Assess 2.0 software for necrosis surface integration. Spray inoculation was used for the B. cinerea development and priming experiment after infection. Leaves of root-treated plantlets with $P$. fluorescens PTA-CT2 or control plantlets were sprayed with the inoculation suspension of $B$. cinerea at $1 \times 10^{6}$ conidia $\mathrm{ml}^{-1}$ using an atomizer, until homogenous coverage of the leaves was reached. Infected plantlets were placed in a growth chamber at $20^{\circ} \mathrm{C}$ with a 16 - and 8-h photoperiod.

\section{RNA extraction and RT-PCR.}

Leaves were directly collected and were ground in liquid nitrogen, whereas roots were washed three times for $1 \mathrm{~min}$ in distilled water prior to freezing, in order to remove adhering bacteria. Three biological replicates of 24 plants per replicate were used for each time point. Total RNA was extracted from $100 \mathrm{mg}$ of leaf or root ground powder following the Concert PlantRNA reagent protocol according to the manufacturer's instructions (Life Technologies). The RNA pellets were resuspended in $30 \mu \mathrm{l}$ of RNAse-free water and were incubated $2 \mathrm{~h}$ at $-20^{\circ} \mathrm{C}$ for solubilization. Genomic DNA was removed by DNAse treatment, according to the manufacturer's instructions (RQ1 RNase-Free Dnase, Promega). First-strand cDNA was synthesized from $150 \mathrm{ng}$ of total RNA using the Verso cDNA synthesis kit (Thermo Scientific).

The expression of targeted genes was monitored in roots and leaves over 5 days of bacterial treatment and only in leaves during $9 \mathrm{~h}$ of $B$. cinerea infection. RT-PCR was performed with Absolute Blue QPCR SYBR Green ROX Mix (Thermo Scientific), using a CFX96 system thermocycler (BioRad). PCR reactions were carried out in duplicates in 96-well plates in a 15- $\mu$ l final volume containing Absolute Blue SYBR Green ROX mix (including Taq polymerase, dNTPs, and SYBR Green dye), $280 \mathrm{nM}$ forward and reverse primers, and 30-fold diluted cDNA. Cycling parameters were 15 min of Taq polymerase activation at $95^{\circ} \mathrm{C}$, followed by 40 two-step cycles composed of $10 \mathrm{~s}$ of denaturation at $95^{\circ} \mathrm{C}$ and $45 \mathrm{~s}$ of annealing and elongation at $60^{\circ} \mathrm{C}$. Following the final cycle of the PCR, the specificity of each amplification was checked using a heat dissociation curve from 65 to $95^{\circ} \mathrm{C}$. Traditional reference genes ( $E F 1 \alpha, 60 S R P, 39 S R P, U B E 2$, and $A D H 2)$ were evaluated with Bio-Rad CFX Manager software v. 3.0 to select those with a stable expression in all tested conditions. The 
expression stability GeNorm $\mathrm{M}$ was below the critical value of 0.5 and the lowest $\mathrm{M}$ value was for the EF1 $\alpha$ and $60 R S P$ genes that were used as internal controls for normalization. Reference samples are leaves or roots of untreated plantlets as the control sample $(1 \times$ expression level). Fold induction values were obtained according to the principle of the formula: $2^{(-\Delta \Delta \mathrm{Ct})}$ with $\Delta \Delta \mathrm{C}_{\mathrm{t}}=\left[\mathrm{Ct}_{\mathrm{GI}}\right.$ (US) $-\mathrm{Ct}_{\mathrm{GR}}$ (US) $]-$ $\left[\mathrm{C}_{\mathrm{tGI}}(\mathrm{CS})-\mathrm{C}_{\mathrm{tGR}}(\mathrm{CS})\right]$, where $\mathrm{C}_{\mathrm{t}}=$ cycle threshold, $\mathrm{C}_{\mathrm{t}}$ value is based on the threshold crossing point of individual fluorescence traces of each sample, GI = gene of interest, GR = gene of reference, $\mathrm{US}=$ unknown sample, and CS = control sample). Integration of the formula for two reference genes was performed by the CFX Manager 3.0 software (BioRad). The results presented are normalized from at least three independent experiments. PCR efficiency of primers was calculated by performing RT-PCR on serial dilutions of cDNA. All tested primer pairs were found to have amplification efficiencies of 90 to $103 \%$.

\section{Phytoalexin analysis.}

Phytoalexins were extracted from leaves and roots as described by Aziz et al. (2006), with few modifications. Plantlet tissues were collected separately and were ground in liquid nitrogen. Samples from powdered leaves $(100 \mathrm{mg})$ and roots $(60 \mathrm{mg})$ were homogenized with $1 \mathrm{ml}$ of $85 \%$ methanol, and then, were incubated on a shaker at $800 \mathrm{rpm}$ in the dark and at room temperature. After $2 \mathrm{~h}$, samples were centrifuged for 10 min at $12,000 \times g$ and supernatants were collected. The remaining pellets were resuspended in $1 \mathrm{ml}$ of $100 \%$ methanol and were incubated for $1 \mathrm{~h}$ in the dark at $800 \mathrm{rpm}$ and then were centrifuged. Supernatants were pooled and dried under a nitrogen stream and the residue was solubilized with $1 \mathrm{ml}$ of $100 \%$ methanol, were filtered through $0.22-\mu \mathrm{m}$ polytetrafluoroethylene filters and were transferred to 2-ml ultraperformance liquid chromatography (UPLC) vials. Stilbenes were also extracted from the culture medium by ethyl acetate $(1: 1 \mathrm{vol} / \mathrm{vol})$. The ethyl acetate phase was completely dried and the residue was suspended in $0.5 \mathrm{ml}$ of methanol prior to injection into the UPLC. Phytoalexins were analyzed using the Ultra Performance Liquid Chromatography Acquity UPLC system (Waters Corp.). Samples $(2 \mu \mathrm{l})$ were injected onto an Acquity UPLC BEH C18 $1.7 \mu \mathrm{m} 2.1 \times 100 \mathrm{~mm}$ column heated to $30^{\circ} \mathrm{C}$. Phytoalexins were eluted with a mixture of water (A) and pure acetonitrile (B) at a flow rate of $0.5 \mathrm{ml} \mathrm{min}-1$ according to the following gradient: initial, $90 \% \mathrm{~A} ; 5 \mathrm{~min}, 10 \% \mathrm{~A} ; 5.5 \mathrm{~min}, 0 \% \mathrm{~A} ; 6 \mathrm{~min}, 0 \% \mathrm{~A}$; $6.5 \mathrm{~min}, 90 \% \mathrm{~A}$; and $7 \mathrm{~min}, 90 \% \mathrm{~A}$. Fluorescence was measured with an excitation wavelength of $330 \mathrm{~nm}$ and an emission wavelength of $375 \mathrm{~nm}$, using an Acquity fluorimeter (Waters). Signals were analyzed using Empower 2 software (Waters), and phytoalexins were quantified after calibration with external standards.

\section{Measurement of anthocyanin.}

For anthocyanin extraction, samples $(100 \mathrm{mg})$ were placed in $1.25 \mathrm{ml}$ of $1 \% \mathrm{HCl}$ in methanol (vol/vol), and then, were incubated overnight in the dark at $4{ }^{\circ} \mathrm{C}$ with gentle shaking. After this process, $0.75 \mathrm{ml}$ of water and $0.75 \mathrm{ml}$ of chloroform were added and mixed to the extract. Chloroform was added to remove chlorophylls by mixing and centrifugation $(15,000 \times g$ for $2 \mathrm{~min})$. The anthocyanin contained in the aqueous phase was recovered and absorbance at $535 \mathrm{~nm}$ was determined spectrophotometrically. The anthocyanin concentrations were calculated using the extinction coefficient of malvidin 3glucoside as reference $\left[\varepsilon=38,000 \mathrm{M}^{-1} \mathrm{~cm}^{-1}\right.$ (Hrazdina et al. 1984)]. All measurements were made in triplicate and were repeated twice.

\section{ACKNOWLEDGMENTS}

This work was partially supported by the Vineal 2 program, and the grant to C. Gruau from the Champagne-Ardenne Region and the City of Reims. We thank B. Courteaux for her technical assistance with grapevine plants.

\section{LITERATURE CITED}

Ait Barka, E. A., Belarbi, A., Hachet, C., Nowak, J., and Audran, J. C. 2000 Enhancement of in vitro growth and resistance to gray mould of Vitis vinifera co-cultured with plant growth-promoting rhizobacteria. FEMS (Fed. Eur. Microbiol. Soc.)Microbiol. Lett. 186:91-95.

Aziz, A., Gauthier, A., Bézier, A., Poinssot, B., Joubert, J.-M., Pugin, A., Heyraud, A., and Baillieul, F. 2007. Elicitor and resistance-inducing activities of $\beta-1,4$ cellodextrins in grapevine, comparison with $\beta-1,3$ glucans and $\alpha-1,4$ oligogalacturonides. J. Exp. Bot. 58:1463-1472.

Aziz, A., Poinssot, B., Daire, X., Adrian, M., Bézier, A., Lambert, B., Joubert, J.-M., and Pugin, A. 2003. Laminarin elicits defense responses in grapevine and induces protection against Botrytis cinerea and Plasmopara viticola. Mol. Plant-Microbe Interact. 16:1118-1128.

Aziz, A., Trotel-Aziz, P., Dhuicq, L., Jeandet, P., Couderchet, M., and Vernet, G. 2006. Chitosan oligomers and copper sulfate induce grapevine defense reactions and resistance to gray mold and downy mildew. Phytopathology 96:1188-1194.

Bakker, P. A. H. M., Pieterse, C. M. J., and van Loon, L. C. 2007. Induced systemic resistance by fluorescent Pseudomonas spp. Phytopathology 97:239-243.

Balmer, D., de Papajewski, D. V., Planchamp, C., Glauser, G., and MauchMani, B. 2013. Induced resistance in maize is based on organ-specific defence responses. Plant J. 74:213-225.

Benhamou, N., and Bélanger, RR. 1998. Induction of systemic resistance to Pythium damping-off in cucumber plants by benzothiadiazole: Ultrastructure and cytochemistry of the host response. Plant J. 14:13-21.

Berendsen, R. L., Pieterse, C. M. J., and Bakker, P. A. H. M. 2012. The rhizosphere microbiome and plant health. Trends Plant Sci. 17:478-486.

Boller, T., and Felix, G. 2009. A renaissance of elicitors: Perception of microbe-associated molecular patterns and danger signals by patternrecognition receptors. Annu. Rev. Plant Biol. 60:379-406.

Bordiec, S., Paquis, S., Lacroix, H., Dhondt, S., Ait Barka, E., Kauffmann, S., Jeandet, P., Mazeyrat-Gourbeyre, F., Clément, C., Baillieul, F., and Dorey, S. 2011. Comparative analysis of defence responses induced by the endophytic plant growth-promoting rhizobacterium Burkholderia phytofirmans strain PSJN and the non-host bacterium Pseudomonas syringae pv. pisi in grapevine cell suspensions. J. Exp. Bot. 62:595-603.

Chassot, C., Buchala, A., Schoonbeek, H.-J., Métraux, J.-P., and Lamotte, O. 2008. Wounding of Arabidopsis leaves causes a powerful but transient protection against Botrytis infection. Plant J. 55:555-567.

Chini, A., Fonseca, S., Fernández, G., Adie, B., Chico, J. M., Lorenzo, O., García-Casado, G., López-Vidriero, I., Lozano, F. M., Ponce, M. R., Micol, J. L., and Solano, R. 2007. The JAZ family of repressors is the missing link in jasmonate signalling. Nature 448:666-671.

Chong, J., Poutaraud, A., and Hugueney, P. 2009. Metabolism and roles of stilbenes in plants. Plant Sci. 177:143-155.

Compant, S., Brader, G., Muzammil, S., Sessitsch, A., Lebrihi, A., and Mathieu, F. 2013. Use of beneficial bacteria and their secondary metabolites to control grapevine pathogen diseases. BioControl 58:435-455.

Conn, S., Curtin, C., Bézier, A., Franco, C., and Zhang, W. 2008 Purification, molecular cloning, and characterization of glutathione $S$-transferases (GSTs) from pigmented Vitis vinifera $\mathrm{L}$. cell suspension cultures as putative anthocyanin transport proteins. J. Exp. Bot. 59: 3621-3634

Conrath, U., Beckers, G. J. M., Flors, V., García-Agustín, P., Jakab, G., Mauch, F., Newman, M. A., Pieterse, C. M. J., Poinssot, B., Pozo, M. J., Pugin, A., Schaffrath, U., Ton, J., Wendehenne, D., Zimmerli, L., and Mauch-Mani, B.; Prime-A-Plant Group. 2006. Priming: Getting ready for battle. Mol. Plant-Microbe Interact. 19:1062-1071.

Conrath, U., Pieterse, C. M. J., and Mauch-Mani, B. 2002. Priming in plantpathogen interactions. Trends Plant Sci. 7:210-216.

De Vleesschauwer, D., and Höfte, M. 2009. Rhizobacteria-induced systemic resistance. Pages 223-281. in: Plant Innate Immunity. L. C. Van Loon, ed. Academic Press Ltd., Elsevier Science Ltd., London.

Doornbos, R. F., Geraats, B. P. J., Kuramae, E. E., Van Loon, L. C., and Bakker, P. A. H. M. 2011. Effects of jasmonic acid, ethylene, and salicylic acid signaling on the rhizosphere bacterial community of Arabidopsis thaliana. Mol. Plant-Microbe Interact. 24:395-407.

Dufour, M. C., Lambert, C., Bouscaut, J., Mérillon, J. M., and Corio-Costet, M. F. 2013. Benzothiadiazole-primed defence responses and enhanced 
differential expression of defence genes in Vitis vinifera infected with biotrophic pathogens Erysiphe necator and Plasmopara viticola. Plant Pathol. 62:370-382.

Erb, M., Lenk, C., Degenhardt, J., and Turlings, T. C. J. 2009. The underestimated role of roots in defense against leaf attackers. Trends Plant Sci. 14:653-659.

Gauthier, A., Trouvelot, S., Kelloniemi, J., Frettinger, P., Wendehenne, D., Daire, X., Joubert, J. M., Ferrarini, A., Delledonne, M., Flors, V., and Poinssot, B. 2014. The sulfated laminarin triggers a stress transcriptome before priming the SA- and ROS-dependent defenses during grapevine's induced resistance against Plasmopara viticola. PLoS ONE 9:e88145.

Gulati, J., Baldwin, I. T., and Gaquerel, E. 2014. The roots of plant defenses: Integrative multivariate analyses uncover dynamic behaviors of gene and metabolic networks of roots elicited by leaf herbivory. Plant J. 77:880-892.

Hrazdina, G., Parsons, G. F., and Mattick, L. R. 1984. Physiological and biochemical events during development and maturation of grape berries. Am. J. Enol. Vitic. 35:220-227.

Iriti, M., and Faoro, F. 2003. Benzothiadiazole (BTH) induces cell-death independent resistance in Phaseolus vulgaris against Uromyces appendiculatus. J. Phytopathol. 151:171-180.

Iriti, M., Rossoni, M., Borgo, M., and Faoro, F. 2004. Benzothiadiazole enhances resveratrol and anthocyanin biosynthesis in grapevine, meanwhile improving resistance to Botrytis cinerea. J. Agric. Food Chem. 52:4406-4413.

Jones, J. D. G., and Dangl, J. L. 2006. The plant immune system. Nature 444:323-329.

Kaplan, I., Halitschke, R., Kessler, A., Sardanelli, S., and Denno, R. F. 2008. Constitutive and induced defenses to herbivory in above- and belowground plant tissues. Ecology 89:392-406.

Kumar, A. S., and Bais, H. P. 2012. Wired to the roots: Impact of rootbeneficial microbe interactions on aboveground plant physiology and protection. Plant Signal. Behav. 7:1598-1604.

Le Hénanff, G., Profizi, C., Courteaux, B., Rabenoelina, F., Gérard, C., Clément, C., Baillieul, F., Cordelier, S., and Dhondt-Cordelier, S. 2013. Grapevine NAC1 transcription factor as a convergent node in developmental processes, abiotic stresses, and necrotrophic/biotrophic pathogen tolerance. J. Exp. Bot. 64:4877-4893.

Léon-Kloosterziel, K. M., Verhagen, B. W. M., Keurentjes, J. J. B., VanPelt, J. A., Rep, M., VanLoon, L. C., and Pieterse, C. M. J. 2005. Colonization of the Arabidopsis rhizosphere by fluorescent Pseudomonas spp. activates a root-specific, ethylene-responsive $P R-5$ gene in the vascular bundle. Plant Mol. Biol. 57:731-748.

Lorenzo, O., and Solano, R. 2005. Molecular players regulating the jasmonate signalling network. Curr. Opin. Plant Biol. 8:532-540.

Lugtenberg, B., and Kamilova, F. 2009. Plant-growth-promoting rhizobacteria. Annu. Rev. Microbiol. 63:541-556.

MacDonald, M. J., and D'Cunha, G. B. D. 2007. A modern view of phenylalanine ammonia lyase. Biochem. Cell Biol. 85:273-282.

Magnin-Robert, M., Trotel-Aziz, P., Quantinet, D., Biagianti, S., and Aziz, A. 2007. Biological control of Botrytis cinerea by selected grapevineassociated bacteria and stimulation of chitinase and $\beta-1,3$ glucanase activities under field conditions. Eur. J. Plant Pathol. 118:43-57.

Marti, G., Erb, M., Boccard, J., Glauser, G., Doyen, G. R., Villard, N., Robert, C. A., Turlings, T. C., Rudaz, S., and Wolfender, J. L. 2013. Metabolomics reveals herbivore-induced metabolites of resistance and susceptibility in maize leaves and roots. Plant Cell Environ. 36: 621-639.

Mendes, R., Kruijt, M., de Bruijn, I., Dekkers, E., van der Voort, M., Schneider, J. H. M., Piceno, Y. M., DeSantis, T. Z., Andersen, G. L., Bakker, P. A. H. M., and Raaijmakers, J. M. 2011. Deciphering the rhizosphere microbiome for disease-suppressive bacteria. Science 332: 1097-1100.

Millet, Y. A., Danna, C. H., Clay, N. K., Songnuan, W., Simon, M. D., Werck-Reichhart, D., and Ausubel, F. M. 2010. Innate immune responses activated in Arabidopsis roots by microbe-associated molecular patterns. Plant Cell 22:973-990.

Mohamed, N., Lherminier, J., Farmer, M.-J., Fromentin, J., Béno, N., Houot, V., Milat, M.-L., and Blein, J.-P. 2007. Defense responses in grapevine leaves against Botrytis cinerea induced by application of a Pythium oligandrum strain or its elicitin, oligandrin, to roots. Phytopathology 97:611-620.

Ober, D., and Kaltenegger, E. 2009. Pyrrolizidine alkaloid biosynthesis, evolution of a pathway in plant secondary metabolism. Phytochemistry 70:1687-1695.

Parage, C., Tavares, R., Réty, S., Baltenweck-Guyot, R., Poutaraud, A., Renault, L., Heintz, D., Lugan, R., Marais, G. A. B., Aubourg, S., and Hugueney, P. 2012. Structural, functional, and evolutionary analysis of the unusually large stilbene synthase gene family in grapevine. Plant Physiol. 160:1407-1419.

Pel, M. J. C., and Pieterse, C. M. J. 2013. Microbial recognition and evasion of host immunity. J. Exp. Bot. 64:1237-1248.

Pieterse, C. M. J., Van der Does, D., Zamioudis, C., Leon-Reyes, A., and Van Wees, S. C. M. 2012. Hormonal modulation of plant immunity. Annu. Rev. Cell Dev. Biol. 28:489-521.

Pieterse, C. M. J., van Wees, S. C. M., Hoffland, E., van Pelt, J. A., and van Loon, L. C. 1996. Systemic resistance in Arabidopsis induced by biocontrol bacteria is independent of salicylic acid accumulation and pathogenesis-related gene expression. Plant Cell 8:1225-1237.

Pineda, A., Zheng, S.-J., van Loon, J. J. A., Pieterse, C. M. J., and Dicke, M. 2010. Helping plants to deal with insects: The role of beneficial soilborne microbes. Trends Plant Sci. 15:507-514.

Pozo, M. J., Van Der Ent, S., Van Loon, L. C., and Pieterse, C. M. J. 2008. Transcription factor MYC2 is involved in priming for enhanced defense during rhizobacteria-induced systemic resistance in Arabidopsis thaliana. New Phytol. 180:511-523.

Sauter, M., Moffatt, B., Saechao, M. C., Hell, R., and Wirtz, M. 2013. Methionine salvage and $S$-adenosylmethionine: Essential links between sulfur, ethylene and polyamine biosynthesis. Biochem. J. 451:145-154.

Schwachtje, J., Minchin, P. E. H., Jahnke, S., van Dongen, J. T., Schittko, U., and Baldwin, I. T. 2006. SNF1-related kinases allow plants to tolerate herbivory by allocating carbon to roots. Proc. Natl. Acad. Sci. U.S.A. 103:12935-12940.

Stein, E., Molitor, A., Kogel, K.-H., and Waller, F. 2008. Systemic resistance in Arabidopsis conferred by the mycorrhizal fungus Piriformospora indica requires jasmonic acid signaling and the cytoplasmic function of NPR1. Plant Cell Physiol. 49:1747-1751.

Tellström, V., Usadel, B., Thimm, O., Stitt, M., Küster, H., and Niehaus, K. 2007. The lipopolysaccharide of Sinorhizobium meliloti suppresses defense-associated gene expression in cell cultures of the host plant Medicago truncatula. Plant Physiol. 143:825-837.

Thines, B., Katsir, L., Melotto, M., Niu, Y., Mandaokar, A., Liu, G., Nomura, K., He, S. Y., Howe, G. A., and Browse, J. 2007. JAZ repressor proteins are targets of the $\mathrm{SCF}\left({ }^{\mathrm{COI} 1}\right)$ complex during jasmonate signalling. Nature 448:661-665.

Timmusk, S., and Wagner, E. G. H. 1999. The plant-growth-promoting rhizobacterium Paenibacillus polymyxa induces changes in Arabidopsis thaliana gene expression: A possible connection between biotic and abiotic stress responses. Mol. Plant-Microbe Interact. 12: 951-959.

Trotel-Aziz, P., Couderchet, M., Biagianti, S., and Aziz, A. 2008. Characterization of new bacterial biocontrol agents Acinetobacter, Bacillus, Pantoea and Pseudomonas spp. mediating grapevine resistance against Botrytis cinerea. Environ. Exp. Bot. 64:21-32.

Trouvelot, S., Varnier, A.-L., Allègre, M., Mercier, L., Baillieul, F., Arnould, C., Gianinazzi-Pearson, V., Klarzynski, O., Joubert, J.-M., Pugin, A., and Daire, X. 2008. A $\beta-1,3$ glucan sulfate induces resistance in grapevine against Plasmopara viticola through priming of defense responses, including HR-like cell death. Mol. Plant-Microbe Interact. 21:232-243.

van de Mortel, J. E., de Vos, R. C. H., Dekkers, E., Pineda, A., Guillod, L., Bouwmeester, K., van Loon, J. J. A., Dicke, M., and Raaijmakers, J. M. 2012. Metabolic and transcriptomic changes induced in Arabidopsis by the rhizobacterium Pseudomonas fluorescens SS101. Plant Physiol. 160: 2173-2188.

Van der Ent, S., Van Hulten, M., Pozo, M. J., Czechowski, T., Udvardi, M. K., Pieterse, C. M. J., and Ton, J. 2009. Priming of plant innate immunity by rhizobacteria and $\beta$-aminobutyric acid: Differences and similarities in regulation. New Phytol. 183:419-431.

Van der Ent, S., Verhagen, B. W. M., Van Doorn, R., Bakker, D., Verlaan, M. G., Pel, M. J. C., Joosten, R. G., Proveniers, M. C. G., Van Loon, L. C., Ton, J., and Pieterse, C. M. J. 2008. MYB72 is required in early signaling steps of rhizobacteria-induced systemic resistance in Arabidopsis. Plant Physiol. 146:1293-1304.

van Hulten, M., Pelser, M., van Loon, L. C., Pieterse, C. M. J., and Ton, J. 2006. Costs and benefits of priming for defense in Arabidopsis. Proc. Natl. Acad. Sci. U.S.A. 103:5602-5607.

van Loon, L. C., Bakker, P. A. H. M., and Pieterse, C. M. J. 1998. Systemic resistance induced by rhizosphere bacteria. Annu. Rev. Phytopathol. 36: 453-483.

Van Peer, R., Niemann, G. J., and Schippers, B. 1991. Induced resistance and phytoalexin accumulation in biological control of Fusarium wilt of carnation by Pseudomonas sp. strain WCS417r. Phytopathology 81: 728-734.

van Wees, S. C. M., Luijendijk, M., Smoorenburg, I., van Loon, L. C., and Pieterse, C. M. J. 1999. Rhizobacteria-mediated induced systemic 
resistance (ISR) in Arabidopsis is not associated with a direct effect on expression of known defense-related genes but stimulates the expression of the jasmonate-inducible gene Atvsp upon challenge. Plant Mol. Biol. 41:537-549.

Van Wees, S. C. M., Pieterse, C. M. J., Trijssenaar, A., Van't Westende, Y. A. M., Hartog, F., and Van Loon, L. C. 1997. Differential induction of systemic resistance in Arabidopsis by biocontrol bacteria. Mol. PlantMicrobe Interact. 10:716-724.

Varnier, A.-L., Sanchez, L., Vatsa, P., Boudesocque, L., Garcia-Brugger, A., Rabenoelina, F., Sorokin, A., Renault, J.-H., Kauffmann, S., Pugin, A. Clément, C., Baillieul, F., and Dorey, S. 2009. Bacterial rhamnolipids are novel MAMPs conferring resistance to Botrytis cinerea in grapevine. Plant Cell Environ. 32:178-193.

Vellosillo, T., Martínez, M., López, M. A., Vicente, J., Cascón, T., Dolan, L., Hamberg, M., and Castresana, C. 2007. Oxylipins produced by the 9-lipoxygenase pathway in Arabidopsis regulate lateral root development and defense responses through a specific signaling cascade. Plant Cell 19:831-846.

Verhagen, B., Trotel-Aziz, P., Jeandet, P., Baillieul, F., and Aziz, A. 2011. Improved resistance against Botrytis cinerea by grapevine-associated bacteria that induce a prime oxidative burst and phytoalexin production. Phytopathology 101:768-777.

Verhagen, B. W. M., Glazebrook, J., Zhu, T., Chang, H.-S., van Loon, L. C., and Pieterse, C. M. J. 2004. The transcriptome of rhizobacteria-induced systemic resistance in Arabidopsis. Mol. Plant-Microbe Interact. 17:895-908.

Verhagen, B. W. M., Trotel-Aziz, P., Couderchet, M., Höfte, M., and Aziz, A. 2010. Pseudomonas spp.-induced systemic resistance to Botrytis cinerea is associated with induction and priming of defence responses in grapevine. J. Exp. Bot. 61:249-260.

Walters, D., and Heil, M. 2007. Costs and trade-offs associated with induced resistance. Physiol. Mol. Plant Pathol. 71:3-17.

Wang, Y., Ohara, Y., Nakayashiki, H., Tosa, Y., and Mayama, S. 2005. Microarray analysis of the gene expression profile induced by the endophytic plant growth-promoting rhizobacteria, Pseudomonas fluorescens FPT9601-T5 in Arabidopsis. Mol. Plant-Microbe Interact. 18: 385-396.

Yedidia, I., Shoresh, M., Kerem, Z., Benhamou, N., Kapulnik, Y., and Chet, I. 2003. Concomitant induction of systemic resistance to Pseudomonas syringae pv. lachrymans in cucumber by Trichoderma asperellum (T-203) and accumulation of phytoalexins. Appl. Environ. Microbiol. 69: 7343-7353.

Zamioudis, C., and Pieterse, C. M. J. 2012. Modulation of host immunity by beneficial microbes. Mol. Plant-Microbe Interact. 25:139150.

Zdor, R. E., and Anderson, A. J. 1992. Influence of root colonizing bacteria on the defense responses of bean. Plant Soil 140:99-107.

Zhang, Y., Gao, M., Singer, S. D., Fei, Z., Wang, H., and Wang, X. 2012. Genome-wide identification and analysis of the TIFY gene family in grape. PLoS ONE 7:e44465.

Zhu, Z., Shi, J., He, M., Cao, J., and Wang, Y. 2012. Isolation and functional characterization of a transcription factor VpNAC1 from Chinese wild Vitis pseudoreticulata. Biotechnol. Lett. 34:1335-1342.

Ziegler, J., and Facchini, P. J. 2008. Alkaloid biosynthesis: Metabolism and trafficking. Annu. Rev. Plant Biol. 59:735-769. 